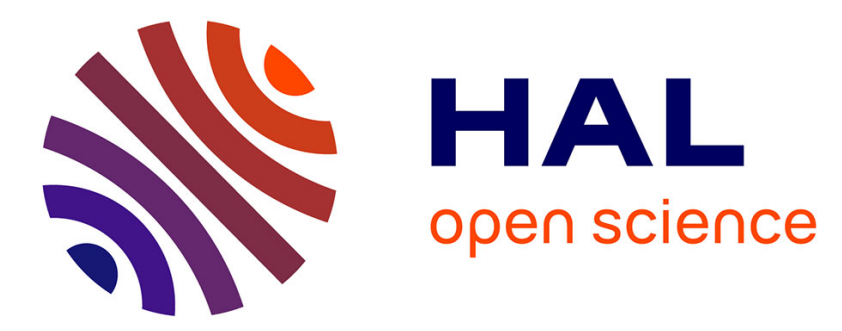

\title{
Changing concepts in the taxonomy of plant pathogenic bacteria
}

\author{
J.M. Young, Y. Takikawa, Louis Gardan, D.E. Stead
}

\section{To cite this version:}

J.M. Young, Y. Takikawa, Louis Gardan, D.E. Stead. Changing concepts in the taxonomy of plant pathogenic bacteria. Annual Review of Phytopathology, 1992, 30, p. 67-105. 10.1146/annurev.py.30.090192.000435 . hal-02712020

\section{HAL Id: hal-02712020 \\ https://hal.inrae.fr/hal-02712020}

Submitted on 1 Jun 2020

HAL is a multi-disciplinary open access archive for the deposit and dissemination of scientific research documents, whether they are published or not. The documents may come from teaching and research institutions in France or abroad, or from public or private research centers.
L'archive ouverte pluridisciplinaire HAL, est destinée au dépôt et à la diffusion de documents scientifiques de niveau recherche, publiés ou non, émanant des établissements d'enseignement et de recherche français ou étrangers, des laboratoires publics ou privés. 


\section{CHANGING CONCEPTS IN THE TAXONOMY OF PLANT PATHOGENIC BACTERIA}

\section{J. M. Young}

DSIR Plant Protection, Private Bag, Auckland, New Zealand

\section{Y. Takikawa}

Plant Pathology Laboratory, Shizuoka University, 836 Ohya, Shizuoka 422, Japan

\section{Gardan}

Station de Pathologie Végétale et Phytobactériologie, Institut National de la Récherche Agronomique, 49070 Beaucouzé, Angers, France

\section{E. Stead}

Central Science Laboratory, Ministry of Agriculture, Fisheries and Food, Harpenden, Hertfordshire AL5 2BD, United Kingdom

KEY WORDS: genera, pathovar, phenetic, phylogeny, species concept

\section{INTRODUCTION}

Bacterial taxonomy, the principles and practice of classifying bacteria, comprises three distinct activities; classification, nomenclature, and identification $(157,171)$. Although these can be conducted as independent activities, we are primarily interested here in the dynamic interactions between them in the on-going public process.

Classification, or grouping, is the arrangement of strains into natural groups (taxa). These groups are based either on a consideration of the overall 
similarities of organisms in phenetic analyses, and therefore are groups about which the greatest number of predictive generalizations can be made (72), or on procedures and systems of analysis considered to show phylogenetic relationships (193). Phenotypic information, gathered by the examination of structure and metabolic activity, can be contrasted with genomic information, obtained by the examination of DNA. Information from RNA is intermediate in form (149). Both phenotypic and genomic information may be analyzed with the intention of generating either phenetic or phylogenetic classifications $(53,72,117,138,147-149,153,176)$. Nomenclature, or naming, involves the allocation of names to circumscribed groups, using the International Code of Nomenclature of Bacteria (99) (the Code) for taxa at the level of subspecies and above, and by the allocation of names or identifying terms to groups at infrasubspecific levels. Identification, or diagnosis, involves the processes by which unidentified isolates are referred to known taxa.

In this review, we briefly survey the history of bacterial taxonomy as it relates to plant pathogenic bacteria and describe current approaches to taxonomy. We discuss species definitions and the application of the term pathovar; the nature of phenetic and phylogenetic classifications; and the effect of recent investigations on the taxonomy of plant pathogenic bacteria. For economy, we refer readers to the Approved Lists of Bacterial Names (144; the Approved Lists and to Young et al (196)) for authorities to names published before 1989. Species names not validated by publication in the Approved Lists or subsequent listing in the International Journal of Systematic Bacteriology are in double quotation marks.

\section{PART 1}

\section{APPROACHES TO TAXONOMY OF PLANT PATHOGENIC BACTERIA}

\section{HISTORICAL PERSPECTIVE}

The taxonomy of plant pathogenic bacteria can usefully be divided into three periods; 1882- 1940, marked by the proliferation of many species names, when the principles of taxonomy for bacteria were relatively undeveloped and when bacteria were often named because they expressed a particular determinative characteristic; $\sim 1940-1975$, when comparative studies indicated large numbers of synonymous or illegal names, and when the principles of classification in phenetic terms were elaborated; and 1975 onwards, when molecular biological methods have increasingly been used to 
generate and to clarify phenetic classification and nomenclature, and in which classifications based on phylogenetic reconstructions have been proposed. This last period has seen dramatic changes in the concepts guiding bacterial classification. In the 1970s, DNA-DNA hybridization (reassociation) studies were instrumental in the revision of classification at the level of genus and species $(98,150)$. The development in the past decade of rapid, efficient methods to extract, purify, and sequence selected elements of DNA and RNA (154) has had a comprehensive and profound effect, leading to a major reevaluation of natural groupings in prokaryotes and eukaryotes at suprageneric levels $(115,155,193)$. Nucleic acid analyses, particularly sequence analyses, can reveal relationships that are not obvious using other methods, but that are usually confirmed by chemotaxonomic investigations (115). At the time of writing, it is difficult to assess how sequence analysis and sequence markers will influence all levels of taxonomy.

Before 1940, large numbers of species names were proposed for distinct plant pathogenic bacteria in various genera (10) including Erwinia and Phytomonas; these two being established to represent plant pathogenic groups. In this early period, descriptions of newly named plant pathogens were often incomplete $(160,170)$, especially for generic circumscriptions, comprising cellular morphology and colony morphology on various media, and relatively small numbers of biochemical tests. A species concept was poorly developed in bacteriology, but a reading of contemporary authority references (5) indicates that plant pathologists were as conscientious as others in their efforts to circumscribe species. The names of some pathogens published during this period are no longer usually recognized because strains were not preserved, the descriptions were not adequate for subsequent identification of strains to the taxa, or because inadequate steps were taken to prove that the bacterium exhibited distinct pathogenic characters.

In the period around 1940, generic classifications were reassessed, allowing the redistribution of most pathogenic species according to their broad similarity groups, in Agrobacterium, Corynebacterium, Erwinia, Pseudomonas, and Xanthomonas. Although these genera may now be seen as representing genomically and phenotypically heterogeneous collections of species, this reclassification allowed more detailed comparative examination of relatively similar organisms. Only when adequate culture collections were made (of which one of the first and most important was Burkholder's progenitor to the International Collection of Phytopathogenic Bacteria), could comprehensive collections be systematically compared and the many differences between species descriptions revealed as the product of differences in method (19). Notwithstanding, there was a strong inclination to think that "where there is a true difference in pathogenic ability, some other type of difference . . . 
cultural, biochemical, metabolic, serological, or some other category . . . should be demonstrable" (19). The application of different names to bacteria with identical pathogenic characteristics was substantially resolved by Elliott (51), who accurately recorded many synonymies. However, conventional approaches to classification that used biochemical and nutritional tests did not reliably produce clearly differentiated species $(19,160)$, particularly in Xanthomonas (44). The conclusion was drawn then $(160,170)$ and supported by subsequent studies $(48,133,167,179)$, that many pathogens were distinguishable largely by differences in pathogenicity. Species classifications based on pathogenicity were considered to give undue weight to these characters. However, there seems to have been a reluctance to follow the suggestion (170) that pathogens be classified at the infrasubspecific level as formae speciales, probably because they were not regulated by any code or rule. Therefore reference to species epithets for distinct pathogens continued to be supported $(45,48,161)$.

This situation might have continued but for reinterpretations in classification and nomenclature that followed the development of methods of numerical analysis (152), coupled with extensive comparative studies, such as those of Stanier et al (159). Such studies gave confidence that bacteria were amenable to order in phenetic classifications, and, together with a critical examination of bacterial names (17), showed how great was the need for a revision of bacterial nomenclature. This need led to the decision contained in the Code to revise bacterial nomenclature by the preparation of Approved Lists. These lists were to include only species for which there was a validly published epithet, a modern description, and at least one authentic strain that could stand as the type strain. These criteria excluded reports of ecological sources such as plant pathogenic characters, distinctive symptoms, or host range as a basis for species definitions in the Approved Lists.

\section{PRESENT PRACTICE IN CLASSIFICATION}

In modern terms, the naming of a taxon according to the Code presupposes that a population of strains has been characterized by a range of methods, generating a description sufficient to circumscribe a taxon as a distinct entity in terms of its overall characteristics, and distinguishing it from all other named taxa $(97,115,146,176)$. Murray et al (115) and Trüper \& Kramer (176) indicate what is intended in modern descriptions. Trüper \& Kramer (176) suggest that descriptions should be based on 25 or more strains, with 10 as a minimum. The treatment of Erwinia cacticida by Alcorn et al (1) can be considered as a model for species descriptions. The Code calls for the 
preparation of minimal standards, to which species descriptions should conform, that should include tests for generic identity, and tests which would distinguish the species from others. Perhaps unfortunately, there is no formal sanction in the Code against names proposed with descriptions that fall short of minimal standards (197). In practice, minimal standards have been proposed and agreed to for few bacterial genera.

Modern practice for naming a new species entails demonstrating that the species is distinct from known species, by the use of polyphasic tests (28). Polyphasic tests include reference to nucleic acid analyses such as DNA-DNA and DNA-rRNA hybridization, as well as chemotaxonomic comparisons such as cell-wall composition, lipid composition, isoprenoid quinones, soluble and total protein, fatty acid profiles, enzyme characterizations (84)). Biochemical and nutritional tests should also be presented as part of a description, but also, essentially, to produce determinative keys $(54,70,75,80,103,111,120)$.

One intention of the Code is to provide an independent reference by which species are circumscribed, and by which strains can be identified as belonging to a known species or as being previously unidentified $(97,176)$. The collected descriptions of taxa in compendia such as Bergey's Manuals of Systematic Bacteriology $(98,150)$ should make it possible to identify any previously classified bacterium. Classifications and nomenclature generated by taxonomists must be usable by diagnosticians to identify strains if there is to be a source of material for future taxonomic study. The importance of determinative tests to identify unknown organisms is often overlooked. If polyphasic tests or specific molecular probes are used solely as the basis for classification, reinstated species or new species and genera would be phenotypically cryptic and difficult to identify $(115,197,198)$. Rapid genomic and chemotaxonomic methods (61) can be used to identify bacteria at the generic and specific levels, although these methods usually require comparisons with reference strains or with libraries of computer-held data. Refinements, such as the automation of methods with computer-stored data bases, using immunology $(64,134)$, fatty acid profiles $(166-168)$, protein or metabolite profiles $(91$, $180,182)$, and nucleic acid-based methodologies (112, 153, 154), may reduce dependence on biochemical and nutritional methods in determinative keys, but has not yet eliminated a need for them in general ecological studies.

Sometimes, inadequate attention is given to the use of authentic reference strains. These are readily available directly from permanent collections such as the American Type Culture Collection (ATCC), Collection Française Bactéries Phytopathogènes (CFBP), International Collection of Microorganisms from Plants (ICMP), Laboratorium voor Microbiologie en Microbiële Genetica, Gent (LMG), and National Collection of Plant Pathogenic 
Bacteria (NCPPB). The practice of serially transferring strains between laboratories results in doubtful authenticity. Culture collection strain designations should not be used unless strains are received directly from a reference collection or unless the history of transfers is indicated.

\section{THE BACTERIAL SPECIES}

The species concept applied to bacteria assumes a population that is asexually reproducing, adapted to a particular environment, and maintained as a distinct stable entity by natural selection. The term species can be applied to populations represented by strains that share high levels of genetic, morphological, metabolic, biochemical, and structural similarity. Bacterial species are based on comparisons of strains and the demonstration of common stable sets of distinguishing characteristics $(62,127)$. If bacteria can be conceived as forming a natural hierarchy in descending taxonomic ranks, then, expressed in phenetic terms, the bacterial species is about the smallest subcluster; groupings below species tend to be determinative rather than phenetic. Decisions on the validity of circumscriptions of species requires a subjective judgment. Apart from differences in judgment as to the robustness of circumscriptions involving the division or amalgamation of subgroups, other problems arise when different comparative methods generate incongruent clusters. These are discussed under genus headings.

\section{Genomic Species}

The term "genomic species" is applied to strains whose DNA-DNA hybridization is greater than some specific value and whose thermal denaturation value is less than some specific value (154). Wayne et al (188) propose a hybridization value of $70 \%$ and a difference in DNA duplex melting temperature of less than $5 \mathrm{C}^{\circ}$. A definition based on these values has served to clarify species relationships in many genera $(98,150)$.

Caution is needed in reconciling classifications at the species level based on phenotypic and DNA-DNA hybridization data available at present. A problem is posed by the sometimes large discrepancies generated between the two approaches. Thus, in Xanthomonas, hybridization values ranged from 0 to $100 \%$ between pathovars (73), which have been shown by analysis of many biochemical tests to be indistinguishable (179). For Pseudomonas, a similar contrast is seen if genomic data (123) are compared with phenotypic data (133). By contrast, in the Enterobacteriaceae, even high hybridization values, usually considered to discriminate species, are associated with phenotypic differences that are considered to differentiate genera (12). Furthermore, the genomic species definition (188) may be difficult to apply where there is 
extensive overlapping of hybridization values, as seems to occur in the Enterobacteriaceae $(12,56)$, in Pseudomonas $(140)$, and almost certainly in Xanthomonas (73). Chromosomal rearrangements could result in changes in the phenotype and restriction fragment length polymorphism (RFLP) patterns without influencing overall sequence similarity (50). The possibility that chromosomal rearrangement could change hybridization values without affecting phenotypic expression must also be considered (96). Such examples emphasize the need for caution in setting arbitrary similarity values to define taxonomic ranks.

DNA-DNA studies are limited largely by technical difficulties in obtaining data and by experimental error (149). Studies reporting complete similarity matrixes for more than small numbers of strains are rare. Thus, there is no complete DNA-DNA similarity matrix dataset, even for type or pathotype strains alone, for coryneform pathogens, or for pathogens in Erwinia, Pseudomonas, or Xanthomonas. The diversity of procedures and possible interpretations (138) emphasizes the importance of standardization and of the need for detailed analyses of results $(65,149)$.

The genomic sequence is proposed as a reference standard (188); sequencing or hybridization data are recommended for the descriptions of new genera (115). However, more needs to be known about the relationship of sequence homology to experimental DNA-DNA hybridization values $(65,149)$. Low (sometimes zero) hybridization values have been reported between phenotypically similar organisms $(73,113,123)$. These results may be explained in part by reference to the structure of DNA and to the stringency of experimental conditions. Short sequences of homologous nucleotides occur at random but are too dispersed to permit annealing (65). At higher homology levels, the detection of homologies by measuring hybridization depends on experimental conditions (138). Because the annealing temperature for sequences containing mismatches (heteroduplexes) falls by $1-1.5 \mathrm{C}^{\circ}$ for every $1 \%$ of unpaired bases (138), for bacterial DNA no hybridization will be detectable with a heteroduplex, even under nonstringent conditions $\left(35^{\circ} \mathrm{C}\right)$, unless there is more than 50-70\% homology between sequences. Clearly, values calculated from hybridization data substantially underestimate \%DNA-DNA homology. Furthermore, the distribution of mismatched bases will be critical in determining the hybridization value expressed by heteroduplexes (11). Values exceeding $100 \%$ (36) indicate experimental error, as may variations in hybridization values of $30 \%$ or more in homogeneous populations considered to be members of a single species $(14,15,36,56)$. The assumption that hybridization values express total DNA-DNA homology (183) is an oversimplification. Hybridization studies should not be taken at face value (65).

The relationship between DNA sequences and encoded proteins also needs clarification. Identical proteins could be encoded by DNA sequences differing 
in the second and third bases in codons, leading to overall sequence differences greater than $30 \%$. Thus localized mismatching at high levels of DNADNA hybridization may only conceal differences between strains due to redundancy in the genetic code (11). The implications of such mismatching for comparative analyses of genomic and phenotypic data have not been investigated.

If the DNA of phenetically similar or identical organisms can differ by as much as $30 \%$ due to redundancy in the genetic code, and if organisms share more than $70 \%$ DNA homology before reassociation is expressed, then it follows that phenetically similar or identical strains may exhibit little or no DNA-DNA reassociation. These factors could explain such observations in Xanthomonas (73). Restriction fragment length polymorphism (RFLP) analyses were reported for differentiating pathovars $(55,66,100,125)$ and for identifying bacterial strains (171). However, RFLP analyses alone are not equivalent to total DNA-DNA hybridization studies $(50,115,181)$. As for all probe methodologies, the discrimination of species or subspecies solely on the basis of RFLP analysis has the same objections and poses the same problems for species classification and nomenclature as does the use of the criterion of pathogenicity to particular plant hosts $(181,197)$.

\section{Pathogenic Speciation and Environmental Adaptation}

Plant pathogenicity has evolved in a relatively small number of diverse bacterial genera (Table 1). Within them, most plant pathogenic species, particularly the coryneform, pseudomonad, and xanthomonad pathogens, are represented by populations of limited competitive saprophytic ability and restricted nutritional requirements $(9,10,24,48,120,133,161)$, presumably because they have evolved common characteristics associated with the ability to grow in the interior environments of higher plants. Within these broad groupings, specific pathogens are commonly represented by populations of low genetic diversity (36). For plant pathogenic bacteria, important complexes of genes in evolutionary and ecological terms are those that adapt the bacteria to their specific host plants. Schaad (135) emphasizes that pathogenic specificity is not given weight in phenetic classification even though it is a primary evolutionary character in determining the ecological fitness of the populations. Specific pathogenicity and resistance genes (158) may represent a small proportion of the genome, and they may not always give expression to large enough differences in the phenotype to justify species (94). The relatively small number of nutritional differences between closely related pathogens may be coincidental to underlying pathogenicity factors, or they may be evolutionary adaptations favoring the specific host-pathogen interaction (74). 


\section{Gene Transfer}

Recently, Maynard Smith (109) reexamined the concept that closely related bacteria, capable of genetic exchange and genetically isolated from other populations, might be considered to represent species in a sense similar to that applied to sexually exchanging populations of eukaryotes. This concept would require substantial investigation before it could form a central position in bacterial taxonomy. At present, it is a matter for speculation whether significant genomic elements can be transferred between unrelated organisms $(11,41,82,85)$. Woese (193) suggested that gene transfer is not a significant evolutionary occurrence, and preliminary investigations suggest that large clusters of genes are not transferred between unrelated organisms (22). Nevertheless, the relative ease with which genetic material can be transmitted between unrelated organisms in the laboratory means that we cannot exclude the possibility that genetic exchange even of short sequences has had a significant influence on the evolutionary record of bacterial taxa, and therefore on their classification (22).

\section{PATHOVARS}

Early suggestions that pathogenicity should have a role in the nomenclature of plant pathogenic bacteria at a ternary, infrasubspecific level $(170,174)$ were not supported for want of detailed proposals. During the compilation of the Approved Lists, it became clear that if the principles of the Code were applied then species names would not be retained for many distinct plant pathogenic bacteria $(43,48,102,133)$. Accordingly, a special-purpose nomenclature was proposed for those plant pathogenic bacteria that did not meet the criteria for species designation $(199,200)$. Following this, the International Society for Plant Pathology established formal standards for the term pathovar (47, 196), complementing the Code (47). The aim was to provide an orderly nomenclature at the infrasubspecific level for bacteria distinguished primarily by differences in pathogenicity.

When the standards for naming pathovars were prepared (47), the definition of pathovar was deliberately proposed in general terms so that the term could evolve, and its definition be exemplified by the way it was used (D. W. Dye, personal communication). The absence of a precise definition may have led to misconceptions as to its intended use, and a more precise definition of the term may be desirable (52). From our present perspective, we review here the application of the term and discuss the underlying assumptions guiding its use.

Pathovar classification and nomenclature is based on the capacity of plant pathogenic bacteria in nature to cause distinctive disease syndromes. The 
infrasubspecies term "pathovar" is applied to bacterial populations, circumscribed by reference to their capacity to cause characteristic symptoms or by reference to their proved host range. These populations are characterized by their distinct pathogenicity mechanisms (implying distinct combinations of pathogenicity genes), but have not been shown to merit classification at a higher taxonomic rank.

Pathogenicity tests are an essential component of the study of plant pathogenic bacteria, and are central to their classification as pathovars (52, 196). Like other bacterial characters, pathogenic reactions are variable. Pathogenic strains may differ in virulence, causing a range of severity of symptoms when inoculated into individual host plant species. Strains may also differ in severity of symptom expression which they cause when inoculated into the different species of their host range. Reliable pathogenicity tests are needed to produce accurate circumscriptions of pathovars in terms of host range (196), and to confirm associations between pathogenic characters and characters that can be used for identification. Reliable tests are also needed as bioassays to elaborate pathogenicity mechanisms, both for taxonomic purposes and for more general studies. Although the principles of plant inoculation have been documented $(95 \mathrm{a}, 137)$ and individual methods are scattered in the literature, as yet there have been no compilations of specific, reliable pathogenicity tests. For some host-pathogen combinations, these have yet to be developed. The symptoms of some bacteria-plant interactions can be difficult to distinguish as compatible or as incompatible reactions but the application of infectivity titrations (51a) offers a way of distinguishing these unambiguously.

Reference above to pathogenicity mechanisms (and distinct combinations of pathogenicity genes) is to make explicit the differences between similar pathogens sharing common hosts, such as P. syringae pv. syringae, P.s. glycinea, P.s. phaseolicola, and P.s.tabaci from bean and soybean. For instance, the production of phytotoxins, syringomycin, coronatine, phaseolotoxin, and tabtoxin (112a) form parts of the circumscriptions of these pathovars, as may other associated characters, and could be used for identification. The identification of pathovars is also easier if account is taken of other characters associated with pathogenicity $(74,199)$. Probe methods $(55,64$, $66,100,112,125,134,154)$ may offer simpler approaches to diagnosis if their specificity to a population's pathogenicity characteristics is proved. Determinative tests can also be used to distinguish pathovars $(35,48,54,75$, $120,178,184,195)$. Because some tests do not always give reliable results, these tests may not invariably distinguish pathovars uniquely, but can usually discriminate between pathovars isolated from one host.

A classification for pathogens should also provide a nomenclature for avirulent strains. Strains proved pathogenic and allocated to a particular 
pathovar which become avirulent, perhaps by cultural attenuation, can straightforwardly be named as avirulent strains of the pathovar. Identification is also possible if isolated strains, avirulent because they are defective in small numbers of mutations to pathogenicity genes, are allocated to particular pathovars using appropriate probes devised to identify pathovars independently of their specific pathogenic character. However, if a strain of a species is made up largely of plant pathogens (e. g. a strain from $P$. syringae or $X$. campestris), is isolated from a source that does not give a clue to its pathogenic capabilities, and if no method is available to prove its identity in a particular pathovar, then identification can only be confirmed to species level. The misunderstanding of the application of pathovars - that they do not offer nomenclature for avirulent strains - arises if pathogenicity tests are seen as the only method of allocating strains to pathovars, rather than as the basis for the circumscription of pathovars. There should be no nomenclatural problem in applying pathovar designations to pathogenic subpopulations of species named as saprophytes (196).

Plant pathogenic species for which it is difficult to give formal expression to pathovar subdivisions are those that have extensive overlapping host-ranges (e.g. E. chrysanthemi) (40). The development of a formal pathovar nomenclature may also have been inhibited in species in which biovar/subspecies groupings are not congruent with pathogenicity groupings (e.g. P. solanacearum) (70). An intractable problem for any nomenclature based on pathogenicity occurs when attempts are made to apply it to pathogens of limited virulence to any host (63).

Confusion can result from the application of a name based on a descriptive character if subsequent comparative studies of related taxa lead to separation of the name from the particular character (see Agrobacterium). Names, including those of pathovars, should be construed only as labels that refer to the associated unique descriptions based on the examination of populations of strains $(146,196)$. Thus, although they can be an aid to recognition, the names "glycinea", "phaseolicola", or "syringae" should not be considered to describe pathovars or species, any more than "ciccaronei", "garcae", or "savastanoi". There should then be no misunderstandings when, as seems likely, some pathovars are reinstated as species, and other pathovars are reallocated these species. A second point of confusion arises when a type strain is construed as necessarily being "typical" of the taxon to which it refers. The type strain is the name-bearer whose function is to determine the taxon to which a name is applied. The name-bearer may be a highly atypical member of its taxon (146). Similarly, a pathotype strain may not have all the pathogenic characters of the pathovar population to which it refers (196).

A feature of useful nomenclature is that it should not be clumsy. The 
unwieldiness of pathovars as trinomials, or ternary names (200), can be obviated in part by the use of contractions (e.g. P. syringae pv. tomato P.s. pv. tomato, P.s. tomato, or pv. tomato) as appropriate $(47,196)$. Unwieldy names are also formed when pathogens are designated as subspecies, and their clumsiness is exacerbated if other pathovars are allocated to them as quaternary names (80a). Such nomenclature may have doubtful utility. Our uncertainties about the taxonomic soundness of subspecies have been expressed above (See The Bacterial Species). If subspecies names are applied to many taxa containing plant pathogens, then plant pathologists might choose between nomenclature that expresses pathogenic relationships and that which expresses natural classification.

It is desirable that the classification of pathogens as pathovars be approached with the same rigor as if they were classified as species. This is most obvious when pathovar terminology is used for such purposes as quarantine legislation. Of course, the need to make accurate circumscriptions of pathogens as such (the need to establish accurate host-ranges, etc) for these purposes is independent of their taxonomic status as infrasubspecies or as higher taxa. Some writers may not have appreciated this point. The application of pathovars has been criticized in general terms $(179,181)$ while other commentaries $(73,74,135,136,139)$ express dissatisfaction with the present state of classification and nomenclature of pathogenic bacteria overall. No alternative approach to the classification and nomenclature of bacterial plant pathogens has been suggested that is concordant with current taxonomic practice. One proposed solution, that pathogens be classified at the species level without comprehensive phenotypic descriptions (161), has found little support.

Most pathovars represent pathogenic species named before 1980. Although Koch's postulates were reported for most of them, inoculation methods were not always devised that gave expression to disease in a reliable way, the extent of their host specificity was often proved only to a limited extent, and therefore the circumscriptions of some of these pathovars are imprecise (161). Pathovars proposed since 1980 have more commonly been reported with detailed descriptions of pathogenicity methods, applied to comprehensive selections of test plants. Since the standards were introduced (47), 22 of the 59 reinstated or newly named plant pathogens have been classified as species and 37 as pathovars.

Because pathogens may conveniently be named as infrasubspecies, the application of pathovars may have discouraged greater endeavors, using the necessary range of genetic or polyphasic methods, to classify them in higher taxa. The fragmented evidence that some pathovars can be reinstated as species needs to be collated for each pathovar and expanded so that formal 
proposals can be considered on their individual merit. Genomic and phenotypic evidence may be sufficient to justify the reinstatement of some pathovars, such as P.s. tomato $(35,36,75)$ and P.s. savastanoi (L. Gardan, personal communication), as species. Perceived similar species should be included in comparative studies if synonymies are to be avoided. The reinstatement of species at present identified as pathovars, and the reallocation of existing pathovars to those species, will result in improved classification.

\section{PHENETIC CLASSIFICATION}

The assumption of classification based on phenetic analyses is that, by comparing large numbers of independent characters of organisms, populations will be grouped in taxa in terms of their overall similarities, and resulting nomenclature will allow predictions to be made about the genomic and phenotypic relationships of the taxa $(32,72,131,147,148,152)$. In the 1960s and early 1970s, bacterial classifications, considered almost entirely in phenetic terms, were derived from numerical analyses of nutritional and biochemical data that used some form of unweighted clustering analysis (145). However, notwithstanding the assumptions of the analysis, these data represented only a very small proportion of the total bacterial phenotype. Except in the most comprehensive studies, the application of biochemical and nutritional data is now largely restricted to establishing determinative tests. Furthermore, because bacteria grow in such a wide range of conditions, it is not possible to conduct comparative biochemical and nutritional studies of different families. Such phenotypic analyses are usually incapable of generating taxonomic ranks above the level of genus. Thus, Buchanan \& Gibbons (16) introduced a discussion on taxonomy with the assertion that the capacity to produce useful hierarchies of bacteria was impossible.

Molecular biological methods applied to genomic data, including the examination of short conserved sequences, indicate relationships $(38,39,120$, $115,155,191)$ that more general chemotaxonomic studies should prove in phenetic terms $(3,20,119,167,173)$. The automation and standardization of analysis of chemotaxonomic tests offers the prospect of treating them quantitatively $(61,91)$. If they can be made reproducible $(138)$, such tests permit the characterization of taxonomic ranks at the generic level $(3,20,71,142,167$, 173) and may be useful for classifying higher taxa.

An important assumption of phenetic classifications is that the various forms of polyphasic data will give congruent classifications. The relative merits of classifications generated by various methodologies can, in principle, be decided in phenetic studies by using various algorithms (131) to compare 
both to the robustness of the classifications and their stability when new data are added (147). This form of resolution is possible if data can be integrated into one form of analysis by an equal weighting of characters. The analysis of data obtained by different methods such as DNA-rRNA hybridization, protein profiling, fatty acid profiling, and nutritional tests for the same collection of strains, has produced incongruent classifications $(115,190)$. If this result expresses a general phenomenon, then the rational integration of these results will depend on more comprehensive investigations than are presently possible. The proposal that DNA-DNA homology data generate matrixes similar to those established by the use of phenotypic data $(74,75)$ needs further analysis in the light of the incongruities reported by Willems et al (190).

Phenetic classifications can be considered natural and evolutionary in the sense that they express bacterial groupings determined by the interplay of natural selection on the phenotype as determined by the genome. However, they do not explicitly aim to show ancestral relationships, accepting the possibility that convergent, parallel, and divergent evolution may have produced taxa whose relationships can no longer be ascertained.

\section{PHYLOGENETIC CLASSIFICATION}

In contrast to the predictive program of phenetic classification, phylogenetic classifications aim to show historical relationships (143). These relationships are sometimes intended to imply evolutionary history (53) or to indicate evolutionary change (117), imprecise definitions also applied to phenetic classification (6). It is surprising how rarely the concept is defined to make clear its specific assumptions and distinct goals $(53,147,148,149)$. Traditionally, the basis of phylogenetic classifications was the establishment of monophyletic taxa (taxa derived from single ancestral groups (143)), which implied the relative times of separation of ancestral lines. Thus, if two taxa from a common ancestor diverge at time $t$ in the past, then they are more closely related to one another than they are to a third taxon with which they share a common ancestor, diverging at time $2 t$ in the past. Furthermore, we would consider two taxa that share a common ancestor at time $t$ in the past to be more closely related than two taxa that shared a common ancestor at time $2 t$ in the past. It seems to us that, even if time can only be measured in relative terms, this parameter forms the basis of the phylogenetic concept. Without evidence that corresponds to an accurate fossil record, attempts to reconstruct bacterial phylogenies can only be conducted indirectly by comparing existing molecular structures. 
It is not possible here to review the considerable literature relevant to the impact on taxonomy of phylogenetic reconstruction by genome comparison or sequence analysis. Recent reviews $(53,117,149,193)$ examine molecular biological approaches to phylogenetic reconstruction. A comprehensive overview is given in Martin (108).

Two important claims have been made about the relationship between phylogenetic reconstruction and taxonomy of bacteria: that sequence and genomic data express phylogenetic relationships; and that phylogeny should determine taxonomy (classification) (188). These claims merit scrutiny.

Do sequence and genomic data express phylogenetic relationships? Wayne et al (188) proposed without elaboration that "the complete DNA sequence would be the reference standard to determine phylogeny." However, for most phylogenetic reconstructions based on sequence analysis, the total genome is explicitly not the basis for a standard (193). Furthermore, if this means that the phylogenetic relationships of bacteria should be determined by a base-bybase comparison of their genomes, then the complete DNA sequence might also be considered to be one reference standard for phenetic analyses. At this level, phylogenetic and phenetic classifications could be considered to coincide. In both cases, the concept of a reference standard needs further explanation.

The proposal that phylogenetic relationships can be inferred from comparisons of overall similarities of genomic data (such as DNA-DNA or DNA-rRNA hybridization) has the same logic as the earlier proposal that these relationships can be inferred from the morphology of organisms, determined by the comparison of selected structures or in overall terms (143). However, this proposition has been formally criticized and appears to be based on doubtful and possibly invalid foundations $(6,7,31)$. Thus, if confusion caused by parallel, divergent, and perhaps convergent evolution is to be avoided, it is necessary to assume that rates of change in compared structures occur at similar rates. However, if, at the same time, it is asserted that different bacterial taxa represent ancestral and recently derived forms (the archaebacteria and enterobacteria as examples) — therefore assuming necessarily different evolutionary rates - then an internal contradiction in the phylogenetic program is implied.

The most striking aspect of the assumptions of reported phylogenetic reconstructions, where these have been made explicit, is their diversity. Thus, if phylogenetic reconstructions aim to reproduce historical relationships between taxa expressed in a way that indicates rates of separation of evolutionary lines, then an essential feature of reconstructions should involve estimates of relative time $(86,148,193)$ and the need for molecular clocks $(175)$. Both selectively neutral sequences and conserved sequences are considered to act 
as molecular clocks (193). However, the capacity for conserved sequences to record time accurately is questionable because structures expressed by extant sequences are governed by function. Conserved sequences are maintained or modified by the selective removal of lethal mutants, and there is no compelling reason to believe that the extent of similarities in remaining sequences expresses a close relationship to time. The rate of change of selectively neutral sequences is so rapid that they are not considered to give useful time scales for most purposes (193). Alternative interpretations of phylogeny as cladistic analyses, applied to the comparison of molecular sequences, establish only the order of separation of ancestral lines. Cladistic analyses do not purport to show relations in time, and debate continues as to whether or not they can be construed to indicate phylogenetic rather than phenetic relationships $(110,122,141,147,148)$.

Methods for phylogenetic reconstruction are also notable in their diversity and sophistication. To the commonly applied methods, such as compatibility, cluster, distance matrix, parsimony, and likelihood $(53,193)$, can be added the subtleties of bootstrap, jack-knife, delete-half jack-knife, etc, and different methods applied as suitable, depending on the nature of the inferred relationships (53). All are the subject of on-going discussion and their application is not uncontroversial.

So far, bacterial phylogenetic reconstructions rest heavily on analyses of the "semiconserved" sequences of this 16s rRNA. This structure represents $\sim 0.04 \%$ of the bacterial genome. Phylogenies based on sequence analyses might be supported if the analysis of other kinds of sequence ( $5 \mathrm{~s}$ rRNA, 23s rRNA, cytochromes, etc) produced congruent reconstructions. However, if such analyses produce anomalies $(2,149)$, then it is not clear by what criteria the "true" phylogeny (156) can be determined (148). The extent to which this taxonomic program is made unstable by the competing claims of phylogenies established by the use of other kinds of sequence, the introduction of other taxa or strains into comparisons, and different forms of analysis $(53,117$, $131,149)$ also needs detailed investigation. Even without the demonstration of anomalies, consideration should be given to what counts as verification for ancient events.

Should phylogeny determine taxonomy (classification)? If phylogenetic reconstructions produced classifications that were effectively unreconcilable with phenetic classification, (if, hypothetically, a species such as Pseudomonas fluorescens was discovered to be an amalgamation by convergent evolution from several bacterial families and, in phylogenetic terms, should therefore be subdivided between families), it is not clear that classifications or the resulting nomenclature so generated would be preferred. The proposition that phylogeny should determine classification is largely unchallenged, perhaps 
because it is such a general statement, but also because it is assumed that phylogenetic and phenetic classifications can ultimately be unified in a single nomenclature.

If phenetic and phylogenetic classifications are not congruent, then the phylogenetic classification necessarily invites nomenclatural proposals for which descriptions of taxa are weak. In the most concise rationale for reconciling phenetic and phylogenetic approaches to classification, Murray et al (115) proposed the following: because the first step in identifying strains is their assignment to genera, the greatest clarity in circumscription and utility in the choice of characteristics must be accorded to this taxonomic level; because it is impractical to identify genera solely by phylogenetic data, they should be characterized by using phenotypic properties, even if the choice of tests changes as better tests are developed; where a disparity exists between phylogenetic and phenotypic data, priority should be given provisionally to the latter until the disparity can be resolved. Whether or not either the comprehensive phylogenetic or phenetic programs are ever completed, this proposal offers the best approach.

Phylogenetic reconstruction is a fascinating and speculative investigation for the natural historian. Its role in taxonomy, specifically in the validation of formal nomenclature, might be more widely supported when proponents of phylogenetic classifications indicate what criteria can be applied to resolve anomalies and what are relevant tests to verify "true" phylogenies. Bacteriologists may not be attracted by classifications and nomenclature based on modeling activities of "what might have happened." They will not welcome conflicting nomenclatural proposals and may elect not to use nomenclature based on these concepts.

\section{SUPRAGENERIC CLASSIFICATION}

Although conserved molecular sequences represent a small proportion of the genome, comparative analyses from diverse bacterial taxa can be used to produce a taxonomic hierarchy. From comparative 16s rRNA sequence analyses, comprehensive representations of bacterial phylogenies have been proposed $(156,193)$ as the basis of bacterial classification (115). These placed a large proportion of Gram-negative bacteria, including most plant pathogens, in a new bacterial class, the Proteobacteria Stackebrandt et al (155). This class also contains a phenotypically heterogeneous collection of phototrophic and chemolithotrophic bacteria. The proposal formalizes taxonomic groupings not yet shown to be phenetic above the generic level.

The class Proteobacteria is divided into subclasses (153) or superfamilies (33) based on DNA-rRNA homology groups. The allocation of genera containing plant pathogens to these subclasses is shown in Table 1. Plant 
pathogens in Pseudomonas, as presently circumscribed, will be divided among at least three families. Hence, pseudomonads closely related to Pseudomonas fluorescens (including $P$. syringae and similar species) in the Pseudomonadaceae are considered to be more closely related to the Enterobacteriaceae, including Erwinia, in the gamma subclass, than to P. solanacearum and $P$. avenae in the beta subclass. Formal steps have been taken with the proposal that the family Comamonadaceae encompass part of the beta subclass (191). This family includes Xylophilus (ampelinus) (syn. Xanthomonas ampelina) (192), as well as Pseudomonas avenae and related pathogens (80), transferred to the genus Acidovorax (192a). The differentiation of genera in the Comamonadaceae rests largely on DNA-rRNA hybridization data both for their circumscriptions and for their identification. The circumscriptions of some genera in the family are based on DNA-rRNA homology data to the exclusion of contradictory phenotypic data provided by SDS-PAGE protein profiles, fatty acid profiles, and nutritional and biochemical tests (190). Critical analyses of data are needed to prove the reliability of this method if it is to be the basis for characterizing closely related taxa (149), such as the genera proposed in the Comamonadaceae. Optimistically, detailed studies of more chemotaxonomic characters will confirm coherent groupings at suprageneric and generic levels, and a phenetic classification of genera will emerge. However, it is not yet clear that there is sufficient genomic or chemotaxonomic information to allow strains to be allocated to these genera without first being identified at the species level and their generic identification made by inference.

A further consequence of characterizing bacterial families solely by DNArRNA annealing temperatures will be that Pseudomonas (in the strict sense) and Xanthomonas will be in separate families. Undoubtedly DNA-rRNA and DNA-DNA data have and will continue to have a central role in classification. Most appropriately it will be used in a unified approach that is not at the expense of phenotypic data. For plant pathogens, the emerging picture is that known pathogens can be allocated to about 12 groups based on phenotypic and genomic data, distinguishable as putative genera. A consequence of recent comparative investigations of taxa has been that nonpathogenic species are being reclassified in genera that have been the repository of plant pathogenic species alone (e.g. Xanthomonas, and atypical species from these genera are being allocated to new genera (e.g. Xylophilus). This process can be expected to produce a more natural classification.

In the absence of a guiding principle, cryptic taxa, including genera, will probably be proposed for which it will be difficult to make diagnoses. Ideally, taxonomy should involve a single formal system $(153,188)$. However, if classifications give rise to nomenclature that require sophisticated technical methods to achieve identifications, then alternative nomenclature will probabaly be used $(97,153,198)$. 


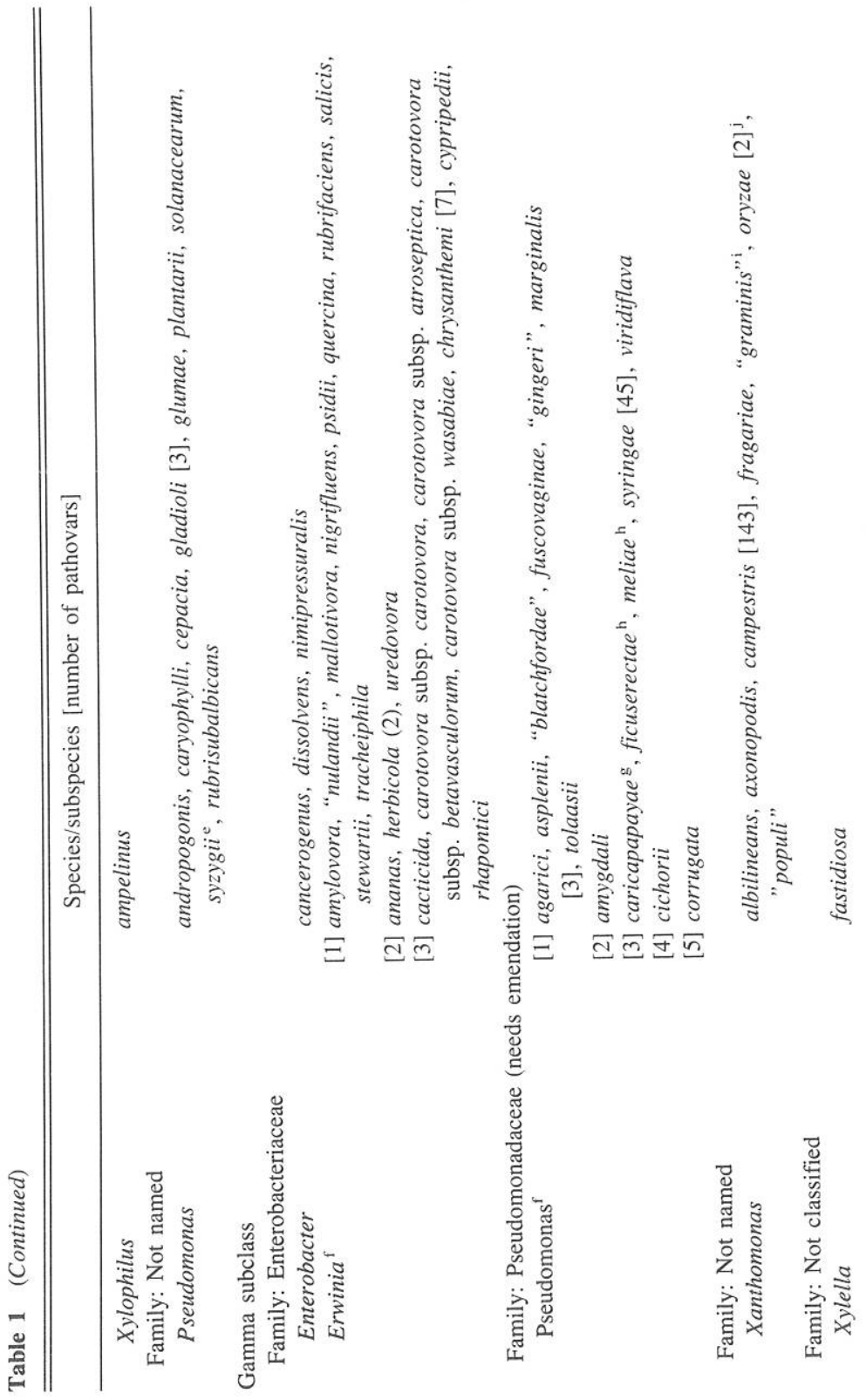




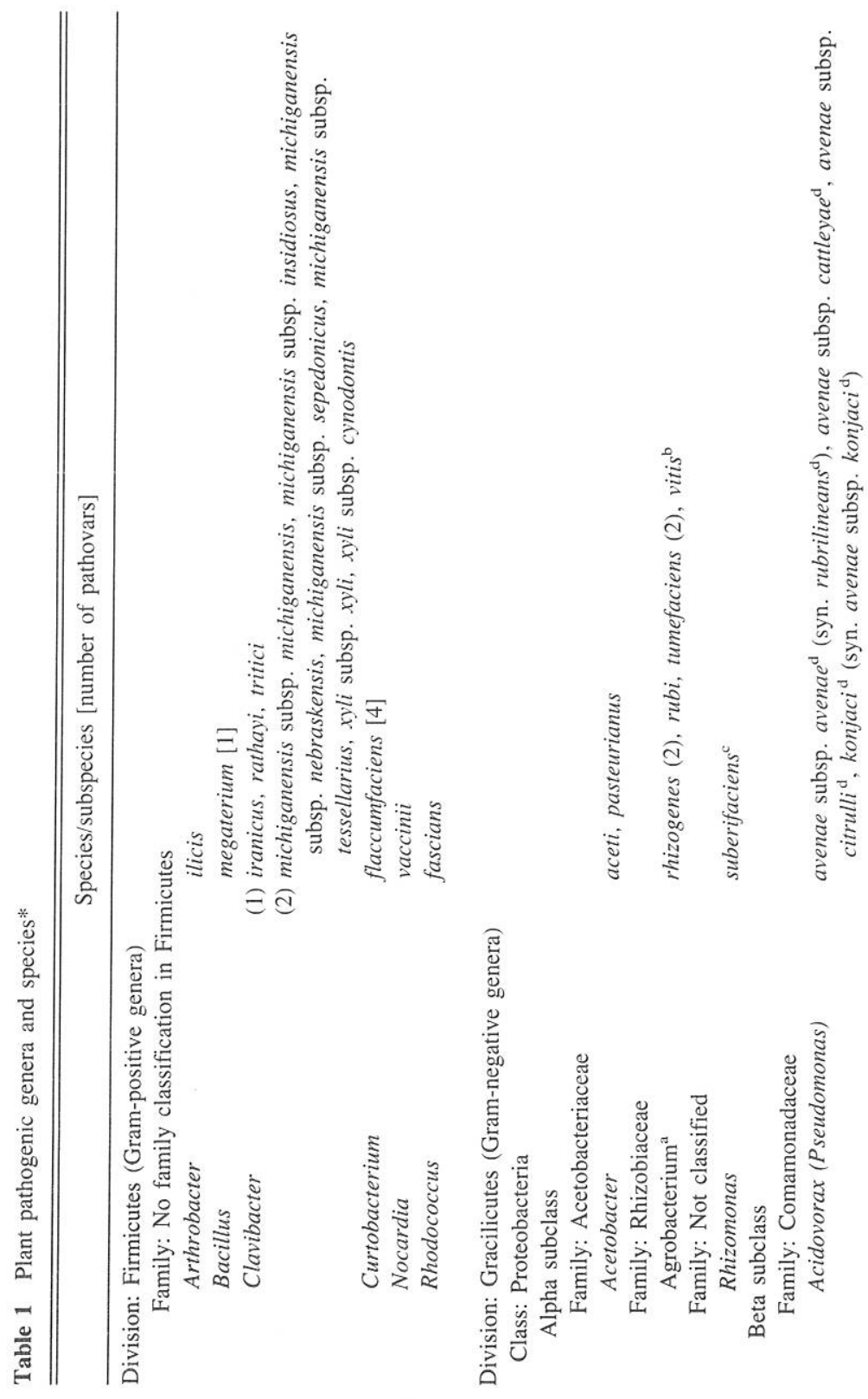




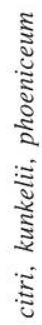
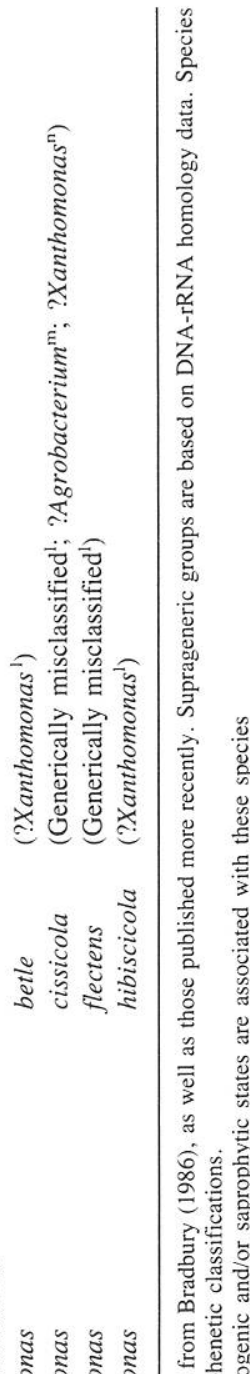

छ

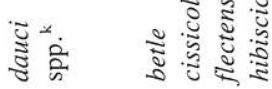
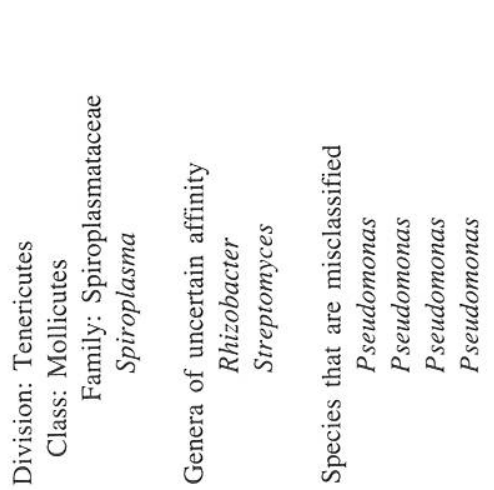

के

\section{ठั山}




\section{PART II}

\section{BACTERIAL GENERA CONTAINING PLANT PATHOGENS}

Genera containing plant pathogens listed in Bradbury (10) and those proposed more recently are listed in Table 1. In the second part of this paper, we examine their current status, taxonomic implications, and specific details relating to particular pathogens. We do not comment on Acetobacter, Bacillus, Rhizobacter, Spiroplasma, or Streptomyces.

\section{Gram-positive Genera}

Although phenotypic and genomic studies had demonstrated that coryneform bacteria, including the plant pathogens, were a heterogeneous group of taxa (30, 48, 81, 194), the Approved Lists included all but one of the Grampositive plant pathogenic genera in Corynebacterium because of their clubshaped (coryneform) morphology. The composition of cell-wall peptidoglycans as well as the cell lipid (mycolic acid) composition and distinct respiratory menaquinones of the coryneform bacteria $(8,24,25)$ indicated distinct patterns corresponding to groupings based on numerical (81) and genomic (42) data. These differences subsequently formed the basis of the phenetic classification by which the genus was subdivided and plant pathogens reallocated $(26,27,31,37)$.

Strictly, Corynebacterium comprises organisms whose cell walls contain a directly cross-linked peptidoglycan based on meso-diaminopimelic acid (DAP), a lipid component containing short-chain mycolic acids, with G.053C ratios of 51-60 mol\%. Plant pathogenic coryneform species do not have these characteristics and therefore have been reclassified into five genera: Arthrobacter, Clavibacter, Curtobacterium, Nocardia and Rhodococcus. The characterization of these genera by direct methods is not simple, although methods have been developed for routine diagnosis (142) and by analysis of whole-organism hydrolysates for characteristic amino-acid, sugar, and lipid patterns $(8,61)$. Comparative studies using nutritional and biochemical tests confirm these natural groupings $(48,106,186)$. Probabilistic methods using smaller numbers of reliable determinative tests for identification may offer efficient procedures (54).

ARTHROBACTER A. ilicis was transferred from Corynebacterium based on an examination of one subculture (NCPPB 1228) of the type strain (27). However, the type strain from another source (ICPB CI144) is a member of Curtobacterium and similar to the only other known strain of the pathogen (47). The most plausible explanation is that the pathogen is a member of Curtobacterium, and that the strain held as the type (NCPPB 1228) is a 
mislabeled strain of Arthrobacter spp. A treatment similar to that applied to Erwinia cacticida (E. carnegieana) (1) could resolve the matter if more strains of the pathogen are isolated.

CLAVIBACTER The distinct cell-wall peptidoglycan of this genus, including the plant pathogens, is based on diaminobutyric acid (DAB) and an absence of mycolic acids. Predominant respiratory menaquinones contain 9 and 10 carbon chains (MK-9 and MK-10), and G+C ratios are 67-68 mol \% (83). Species transferred to Clavibacter from Corynebacterium (31) are listed in Table 1. Past investigations of coryneforms have not been focused on the species within currently recognized genera, with the result that heterogeneous subgeneric groups may not have been as clearly defined as might now be possible. C. iranicus, $C$. rathayi, and $C$. tritici may be part of a discrete group, separable from other members of Clavibacter (128; L. I. Evtushenko, personal communication). It is difficult to assess the taxonomic rank to which the pathogens previously recognized either as pathovars (48) or as subspecies (21) of $C$. michiganensis should be referred. Although chemotaxonomic analyses $(71,129)$ suggest recognition of separate species, a preliminary DNA-DNA hybridization study (42) indicated such high similarity between strains of $C$. michiganensis subsp. michiganensis and C. michiganensis subsp. insidiosus that their reinstatement as species seems unlikely. The genus also includes two distinct, nutritionally fastidious organisms, the stunting pathogens, $C$. xyli subsp. xyli and the problematic pathogen, $C$. xyli subsp. cynodontis.

CURTOBACTERIUM The distinct cell-wall peptidoglycan of this genus, including the plant pathogens, is based on ornithine, and no mycolic acids are present. MK-9 is the predominant respiratory menaquinone, and $\mathrm{G}+\mathrm{C}$ ratios are $68-75 \mathrm{~mol} \%$ (83). Plant pathogens were transferred to the single plant pathogenic species (26) namely $C$. flaccumfaciens, comprising the pathovars $C$.f. flaccumfaciens, C. $f$. betae, $C$. $f$. oortii, and $C$. $f$. poinsettiae. DNADNA homologies between these pathovars exceeding $70 \%$ (42) together with common fatty acid profiles (71) indicate that this nomenclature is probably sound. A few determinative tests can be used to discriminate the pathovars (48).

NOCARDIA AND RHODOCOCCUS $N$. vaccinii was always distinguished by its morphology (34) and has subsequently been confirmed as distinct from other plant pathogens $(59 \mathrm{a}, 60)$. Goodfellow (57) proposed the transfer of Corynebacterium fascians to Rhodococcus. $R$. fascians and $N$. vaccinii are the single plant pathogenic species of these nocardioform genera. From their cell-wall structures, members of these genera are considered to be closely related to Corynebacterium $(58,101)$. 


\section{Gram-negative Genera}

AGROBACTERIUM The genus Agrobacterium was established to include related soil-inhabiting bacteria and gall-forming pathogens. The affinity of these organisms to the fast-growing strains of Rhizobium in the alpha subclass of the Proteobacteria, and the possibility of their amalgamation in a single genus, has been noted $(89,90,92)$.

The names A. tumefaciens and A. rhizogenes were originally applied to strains with tumor-inducing and root-inducing capacity, respectively, and these names have become closely associated with these pathogenic characters. Most of the genes for tumor induction are carried on interchangeable plasmids (116). The recognition that pathogenicity was transmissible and that species should be distinguished by phenotypic and genomic comparisons led to the proposal that pathogenicity be distinguished at the ternary level $(78,90)$. There are two taxa circumscribed by phenotypic and genotypic analyses (78, $88,93)$ to which the names A. tumefaciens and A. rhizogenes should be applied independently of pathogenicity $(10,77,78)$. Two further species have been described based on phenotypic and genomic studies: A. rubi and A. vitis Ophel \& Kerr (118). At present, only tumorigenic and nonpathogenic strains of these species are known. The taxa A.tumefaciens, A. rhizogenes, and A. vitis correspond to biovars 1, 2, and 3, respectively, of Keane et al (88).

A. tumefaciens and the nonpathogenic soil-inhabiting $A$. radiobacter are considered to be synonyms $(89,92)$. Although A. radiobacter, was named first, for reasons that are not clear, A. tumefaciens was conserved over the earlier-named species as the type species (87).

Uncertainty in the nomenclature of Agrobacterium occurs because the species epithets are closely associated with pathogenicity. Notwithstanding our earlier comments on the distinction between names and descriptions, the unique application of the epithets "tumefaciens" and "rhizogenes" to species that do not have the implied pathogenic character, or to species with the conflicting pathogenic character (e. g. A. tumefaciens pv. rhizogenes), is a continuing source of confusion. If names are considered without reference to their descriptive connotations, then in current nomenclature, Agrobacterium comprises the species A. tumefaciens, A. rhizogenes, A. rubi, and A. vitis, and where appropriate, pathogenicity can be designated by reference to their tumorigenic, rhizogenic, or saprophytic (nonpathogenic) states (78). Kersters \& De Ley (92) proposed that $A$. radiobacter be conserved over $A$. tumefaciens and that a new name be applied to A. rhizogenes. This radical proposal would allow the application of the terms "tumefaciens" and "rhizogenes" at a ternary level as pathovars (192) to strains with particular pathogenic characters, but it would require formal presentation to the Judicial Commission of the International Committee on Systematic Bacteriology, with names, descriptions, and neotypes. Had the proposal of Kerr et al (90) been adopted before the 
Approved Lists were published, the nomenclature of Agrobacterium could subsequently have been resolved without recourse to the official nomenclatural authority.

ERWINIA The genus Erwinia was first proposed for plant pathogenic bacteria that were rods, motile by peritrichous flagella, and subsequently further circumscribed as facultative anaerobes. Excepting the inclusion of $E$. herbico$l a$ and E. persicinus Hao et al 1990, the genus comprises plant pathogenic bacteria. The genus has been the subject of a number of numerical analyses of biochemical and nutritional tests $(45,111,185)$. Other descriptive literature has been summarized recently $(104,124)$.

Waldee (187) considered that Erwinia should be restricted to E. amylovora and to pathogenic species causing diseases involving necrosis, and proposed the genus Pectobacterium for E. carotovora and species causing diseases involving tissue rots. These proposals have not found general support because there were no adequate circumscriptions of the genera. Species included in Pectobacterium because of their pectolytic character were not considered to form a natural group based on more general phenotypic considerations (104).

The difficulties of classification for Erwinia can best be unraveled by first considering the long-debated taxonomic position of $E$. herbicola. The accumulated evidence $(4,14)$ indicated the similarity of strains of $E$. herbicola from plant tissue and terrestrial environments to those of Enterobacter agglomerans from human and animal sources. Beji et al (4) proposed the synonymy of Erw. herbicola as a junior synonym of Ent. agglomerans. Subsequently, the results of DNA-DNA hybridization and protein electrophoresis and a re-evaluation of the earlier published data led Gavini et al (56) to propose that strains of Erw. herbicola/Ent. agglomerans be reclassified in a new genus, subdivided as two species, Pantoea agglomerans and $P$. dispersa. The circumscription of the genus Pantoea depends largely upon genomic differences supported by protein electrophoresis studies and by earlier genomic analyses (14). Some strains included in the analysis, identified as Ent. agglomerans by Brenner's group, were excluded from Pantoea. Therefore, unless the circumscription of Pantoea is revised, the creation of at least one further species for those herbicola/agglomerans strains seems to be implied. The results of homology studies that used other reference strains from this species group could produce a more complex pattern of similarities. The phenotypic circumscription of the genus Pantoea would not allow strains to be distinguished from other genera. Perhaps, like Pseudomonas fluorescens, the heterogeneity of this saprophytic organism might be better expressed by its subdivision into biovars of a single species (120).

These proposals to reclassify $E$. herbicola into a separate genus has important implications for the classification of the remaining Erwinia spp. and for 
the Enterobacteriaceae overall. Although Perombelon (124) has noted the difficulties in dividing Erwinia spp., phenotypic studies (45, 111, 185) indicate three subgroups: (a) E. amylovora, E. tracheiphila, E. quercina, E. rubrifaciens, E. salicis, and E. stewartii; (b) E. herbicola, E. ananas, and E. uredovora; and (c) E. carotovora and its subspecies and E. chrysanthemi. Therefore, acceptance of the reclassification of E. herbicola in Enterobacter or Pantoea implies the division of Erwinia into at least two genera of plant pathogenic species. This division could see the reclassification of the carotovora/chrysanthemi group either in a new genus or perhaps in an emended description of Pectobacterium. However, it is not yet clear if a coherent reclassification will be supported by detailed genomic analyses. Comparisons based on $\mathrm{G}+\mathrm{C}$ ratios indicate that $E$. carotovora and its subspecies, together with E. rubrifaciens, E. salicis and E. tracheiphila form one group and E. amylovora and E. chrysanthemi form another group (162). Furthermore, DNA-DNA hybridization studies indicate that some Erwinia species are as genomically similar to one another as they are to species in other genera of the Enterobacteriaceae $(15,56,114,169)$.

Phenotypic comparisons that include species from other genera of the Enterobacteriaceae show these interspersed among Erwinia spp. (111). It follows that these studies are not yet comprehensive enough to produce a resolution of Erwinia spp. unless a substantially larger component of the Enterobacteriaceae is also included. The extent of genotypic and phenotypic heterogeneity underlines the need for further study before a rational classification of the family is achieved. The temptation to divide Erwinia spp. among phenotypically cryptic genera should be avoided (124). Before further genera are proposed, criteria for their circumscriptions within the Enterobacteriaceae should be considered.

The division of E. chrysanthemi into pathovars (47) is loosely correlated with groupings as serovars and biovars (132). However, strains of these groups exhibit overlapping host ranges, making implausible a formal nomenclature based on pathogenicity (40). The species represents a heterogeneous population and is not easily subdivided at the infraspecific level.

The confused nomenclature of E. carnegieana, the pathogen of saguaro cactus, has been resolved by publishing a new name for the pathogen, $E$. cacticida (1).

Recently, three other species were reclassified as Enterobacter cancerogenus, Ent. dissolvens, and Ent. nimipressuralis (15). These species are represented by small numbers of strains of unconfirmed pathogenicity and their status is uncertain.

PSEUDOMONAS At present, species of Pseudomonas are conventionally grouped according to whether or not they produce fluorescent pigments on iron-deficient media and poly- $\beta$-hydroxybutyrate inclusions (70). However, 
genomic $(38,39,120)$, chemotaxonomic $(3,21,119,167,173)$, and biochemical and nutritional $(151,159)$ investigations indicate that the genus as circumscribed comprises several natural groups that could be reclassified as separate genera. Three DNA-rRNA homology groups containing plant pathogenic pseudomonads have been identified $(38,39,120)$.

The fluorescens group The fluorescens group comprises those species, most strains of which produce fluorescent pigments that are considered to be members of Pseudomonas, defined in a strict sense, and classified in the gamma subclass of the Proteobacteria (155) in the Pseudomonadaceae. $P$. corrugata, anomalous in this group (39), is a nonfluorescent, poly- $\beta$ hydroxybutyrate positive species. The fatty acid profiles of " $P$. gingeri" and " $P$. blatchfordae" indicate that these also are part of the fluorescens group (167; D. E. Stead, unpublished data). Within this group, there are three subgroups based on DNA-DNA hybridization reactions, two of which contain plant pathogenic species (120). One subgroup includes pathogens associated with $P$. fluorescens, namely $P$. marginalis (Table 1). The other subgroup includes species related to $P$. syringae, as well as pathogens associated with $P$. syringae as pathovars (Table 1).

Pseudomonas syringae Originally isolated from lilac (Syringa vulgaris L.), $P$. syringae was the name applied to a bacterial plant pathogen that was subsequently identified from host species of many genera and families (51) and reclassified as $P$. syringae pv. syringae. This pathovar name was reserved for pathogens sharing hosts in common with the organisms originally from lilac. Unfortunately, P.s. syringae has tended to be the repository of many strains from many hosts, without any demonstration that these strains share a common host or hosts (10). Strains isolated from many such hosts probably represent a number of pathovars or independent species (195). This species may also live separately from host plants as a saprophyte (76) though the restricted capacity of strains to utilize simple substrates when compared with strict saprophytes (133) suggests that this may be limited.

At present, 45 pathovars are recognized. The pathovars of $P$. syringae, $P$. s. aceris, $P$. s. aptata, $P$. s. atrofaciens, $P$. s. dysoxyli, $P$. s. japonica, $P$. s. lapsa, $P$. s. panici, $P$. s. pisi, and $P$. s. papulans appear to be closely related to P.s. syringae and some may be synonyms (55a, 140; J. M. Young, unpublished data). Other pathovars may also be synonymous. Thus, unpublished data (M. N. Schroth, personal communication) indicates that P.s. antirrhini, P.s. maculicola, and P.s. tomato may share a common hostrange.

DNA-DNA hybridization studies of representative pathovars $(123,140)$ indicate a number of homology groups each containing several pathovars. These are difficult to circumscribe as discrete taxa because clusters es- 
tablished by using the reference DNA of one pathovar overlap with clusters produced by using reference DNA of other pathovars. Protein profiles produce discrete groups for some pathovars (180). Fatty acid profiles of pathovars of $P$. syringae produced 13 groups (167) but these groups do not correspond to those generated by DNA-DNA hybridization studies (140). If $P$. syringae is subdivided into a number of species the remaining pathovars will necessarily be distributed among them. A small number of nutritional and biochemical determinative tests discriminate between 20 pathovars and allow their identification from known hosts $(75,120)$.

The solanacearum group The nonfluorescent pathogenic species, $P$. andropogonis (syn. P. woodsii), P. caryophylli, P. cepacia, P. gladioli, P. glumae, $P$. solanacearum, $P$. syzygii Roberts et al (130) and $P$. rubrisubalbicans, are part of a solanacearum DNA-rRNA homology group $(38,39,120)$ that merits reclassification as a separate genus when comprehensively circumscribed. This genus would be part of an as yet unnamed family of the beta subclass of the Proteobacteria. Individual species are considered to be well described (120). Except for $P$. rubrisubalbicans, which has affinities with the fluorescent pseudomonads, the members of this group also share common fatty acid profiles (168). The fatty acid profile of $P$. plantarii indicates that it also is part of this group $(168,173)$.

Pseudomonas solanacearum $P$. solanacearum is a species of taxonomic and pathogenic complexity not given to simple subdivision. Three races have been identified according to the plants that they affected (18). Within these groups, numerous pathotypes are indicated (18), but these have never been circumscribed formally as pathovars. Hayward (68) identified four biovars based on phenotypic characterization. The biovars are not compatible with the race distinctions, and both classifications have been used since. Cook et al (29) recently identified subgroups of strains within $P$. solanacearum by RFLP analysis that corresponded to the geographic sources of the strains.

The acidovorans group The acidovorans DNA-rRNA homology group (39, 120) was recently reclassified as the family Comamonadaceae in the beta subclass of the Proteobacteria (191). Species in this group are $P$. avenae, $P$. cattleyae, P. pseudoalcaligenes subsp. citrulli, P. pseudoalcaligenes subsp. konjaci, $P$. rubrilineans, and Xylophilus ampelinus. Based on phenotypic and DNA-DNA hybridization studies $(80,126)$, these Pseudomonas spp. were considered to be members of a single species, $P$. avenae. $P$. cattleyae and $P$. rubrilineans were considered to be synonyms of $P$. avenae subsp. avenae, and the subspecies of $P$. pseudoalcaligenes were reclassified as $P$. avenae subsp. citrulli (Schaad et al 1978) Hu et al (80) and $P$. avenae subsp. konjaci 
(Goto 1983) Hu et al (80). In a recent, more detailed study, these taxa have been transferred to the genus Acidovorax, as A. avenae subsp. avenae, A. avenae subsp. cattleyae (Pavarino 1911) Willems et al (192a), avenae subsp. citrulli (Schaad et al 1978) Willems et al (192a), and A. konjaci (Goto 1983) Willems et al (192a).

RHIZOMONAS This genus is represented by a single species Rhizomonas suberifaciens Van Bruggen et al (177), the causal agent of corky root of lettuce. Studies of morphological and physiological characters, as well as comparisons of DNA-DNA hybridization and fatty acid profiling, show that this species has affinities with Pseudomonas (Sphingomonas) paucimobilis and is more closely related to Agrobacterium and Acetobacter in the alpha subclass of the Proteobacteria than to other genera containing plant pathogens (177).

XANTHOMONAS This genus includes more pathogens than all other genera combined. In the first comprehensive comparative phenotypic study of the genus, Dye (44) showed that most species could not be distinguished from $X$. campestris. Subsequently, 5 distinct species of Xanthomonas and more than 110 pathogens were recorded in X. campestris (49). Recently, a comprehensive phenotypic analysis (179) largely confirmed Dye's (49) results. Xanthomonas now comprises eight taxa, seven of which are plant pathogens, which may be distinguishable phenotypically as species (Table 1). On the basis of DNA-DNA hybridization and phenotypic data, X. oryzae (ex Ishiyama 1922) Swings et al (172) was reinstated and includes the pathovars, X.o. oryzae and X.o. oryzicola. One or more further species, centered on strains from other graminaceous hosts, are also indicated $(94,165,178,179$, 182). All Xanthomonas strains tested so far, including the nonpathogen, $X$. maltophilia, share several branched hydroxy fatty acids. The presence of the two branched hydroxy acids $11: \mathrm{O}$ iso $3 \mathrm{OH}$ and $13: \mathrm{O}$ iso $3 \mathrm{OH}$ seems to be unique to Xanthomonas (168), and offers a determinative test for the genus as circumscribed at present. Recently, it has been argued that the phenotypic difference between $X$. maltophilia and all other Xanthomonas spp. are so large that this species should be reallocated to a separate but related genus (180a).

Xanthomonas campestris $X$. campestris now contains 143 pathovars with a host range extending to more than 66 monocotyledonous and 160 dicotyledonous genera (105). Within the species, several subgroups can be discerned from differences in DNA-DNA homology, and protein and fattyacid profiles. 
Early DNA-DNA homology studies (113) suggested that there existed in X. campestris distinguishable genomic species in the sense of Wayne et al (188). However, DNA-DNA hybridization values were sufficiently high $(>50 \%)$ (113) that only replicated studies, with careful attention to method and details of stringency, would determine if they were separable as species. Several DNA-DNA subgroups are indicated $(73,181)$. These studies await confirmation and extension. Clearly, several unclassified genomic species exist at present in X. campestris. The technical difficulty of gathering hybridization data has meant that all comparisons are incomplete except those involving small numbers of strains.

Comprehensive studies of fatty acid profiles have indicated several subgroupings within $X$. campestris (181). Thus, for the pathogens from grasses and cereals, several pathovars formed a single cluster, whereas others formed discrete profiles (165). The association between specific fatty acid profiles and the host range of pathovars is recorded for a wider range of pathovars (181).

Protein profiling is at a preliminary stage in the investigations of $X$. campestris $(94,178,180-84)$. Profiling data will be open to comparative analysis if standardized methods for particular protein groups are maintained. A comprehensive study showed that many pathovars are represented by homogeneous protein patterns, but that some protein patterns encompass several pathovars (182). Disconcertingly, the groupings indicated by this method do not confirm those formed when using DNA-DNA hybridization data (73), in some cases using the same strains.

The various polyphasic approaches to the taxonomy of $X$. campestris give confidence that phenetic analyses will permit the further reinstatement of species from this heterogeneous taxon. However, these should wait until the anomalies indicated by present studies are resolved. Even if $X$. campestris is subdivided into as many as 20 species, the remaining 120 pathovars will necessarily be distributed among them.

XYLOPHILUS $X$. ampelinus was originally classified in Xanthomonas (121) but was shown to be a member of the acidovorans DNA-rRNA group (192) (Comamonadaceae), with $P$. avenae, but recognizable as a genomically and phenotypically distinct genus.

XYLELLA Until recently, diseases from a range of unrelated plants were attributed to "rickettsia-like" organisms. The successful isolation and culture of a fastidious, xylem-limited bacterium was followed by its classification in a new genus as Xylella fastidiosa. Data from 16S rRNA sequence analyses indicate affinities with the xanthomonads in the gamma subgroup of the 
Proteobacteria (189). Preliminary studies, restricted by difficulties in culturing the organisms, indicate complex infraspecific phenotypic and pathogenic relationships (79).

\section{EPILOGUE}

Publication of the Approved Lists in 1980 represented a synthesis of existing taxonomic data, recognized as incomplete, in a formal nomenclature reflecting the perception of bacterial classification at the time. Since then the formation of extensive and diverse bodies of data has brought, and will continue to bring, progress in the refinement of bacterial classification. They may produce nomenclature that will be more difficult to apply than in the past. Recent taxonomic data are subject to various interpretations, and is sometimes difficult to reconcile and assimilate in a unified way. Hayward's (69) appeal for stability in nomenclature remains relevant. Formal nomenclature should be generally recognized as only a guide to the complexities of the natural relationships of bacteria, and the use of a nomenclature may entail a qualified commitment to particular classifications. Such an approach may ease occasional tension between the activities of classification, naming, and diagnosis; and bacteriologists, including plant pathologists, should feel better able to view the present and prospective dynamic processes of reclassification and renaming as constructive efforts towards communication and understanding.

\section{Literature Cited}

1. Alcorn, S. M., Orum, T. V., Steigerwalt, A. G., Foster, J. L. M., Fogleman, J. C., et al. 1991. Taxonomy and pathogenicity of Erwinia cacticida sp. nov. Int. J. Syst. Bacteriol. 41:197-212

2. Ambler, R. P. 1985. Protein sequencing and taxonomy. See Ref. 59, pp. 307-35

3. Auling, G., Busse, H-J., Pilz, F., Webb, L., Kneifel, H., et al. 1991. Rapid differentiation, by polyamine analysis, of Xanthomonas strains from phytopathogenic pseudomonads and other members of the Proteobacteria interacting with plants. Int. J. Syst. Bacteriol. 41:223-28

3a. Balows, A., Truper, H. G., Dworkin, M., Harder, W., Schleifer, K-H. 1992. The Prokaryotes-A Handbook on the Biology of Bacteria: Ecophysiology, Isolation, Identification, Applications. Vols. 1-4. New York: Springer-Verlag. 1027 pp., 1113 pp., 9991 pp., 995 pp. 2nd ed.

4. Beji, A., Mergaert, J., Gavini, F.,
Izard, D., Kersters, K., et al. 1988. Subjective synonymy of Erwinia herbicola, Erwinia milletiae (sic), and Enterobacter agglomerans and redefinition of the taxon by genotypic and phenotypic data. Int. J. Syst. Bacteriol. 38:77-88

5. Bergey, D. H. 1934. Bergey's Manual of Determinative Bacteriology. Baltimore: Williams \& Wilkins. 664 pp. 4th ed.

6. Bigelow, R. S. 1958. Classification and phylogeny. Syst. Zool. 7:49-59

7. Bigelow, R. S. 1959. Similarity, ancestry and scientific principles. Syst. Zool. 8:165-68

8. Bousfield, I. J., Callely, A. G., eds. 1978. Coryneform Bacteria. London: Academic. 315 pp.

9. Bradbury, J. F. 1984. Xanthomonas Dowson 1939. See Ref. 98, pp. 199-210

10. Bradbury, J. F. 1986. Guide to the Plant Pathogenic Bacteria. Kew: CAB Int. Mycol. Inst. 332 pp. 
11. Bradley, S. G. 1980. DNA reassociation and base composition. In Microbial Classification and Identification, ed. M. Goodfellow, R. G. Board, 11-26. London: Academic. 408 pp.

12. Brenner, D. J. 1984. Enterobacteriaceae Rahn 1937. See Ref. 98, pp. 408-20

13. Brenner, D. J., Fanning, G. R., Leete Knutson, J. K., Steigerwalt, A. G., Krichevsky, M. I. 1984. Attempts to classify herbicola group-Enterobacter agglomerans strains by deoxyribonucleic acid hybridization and phenotypic tests. Int. J. Syst. Bacteriol. 34:45-55

14. Brenner, D. J., Fanning, G. R., Steigerwalt, A. G. 1977. Deoxyribonucleic acid relatedness among Erwiniae and other enterobacteria. II. Corn stalk rot bacterium and Pectobacterium chrysanthemi. Int. J. Syst. Bacteriol. 27:21121

15. Brenner, D. J., McWhorter, A. C., Kai, A., Steigerwalt, A. G., Farmer, J. J. 1986. Enterobacter asburiae sp. nov., a new species found in clinical specimens, and reassignment of Erwinia dissolvens and Erwinia nimipressuralis to the genus Enterobacter as Enterobacter dissolvens comb. nov. and Enterobacter nimipressuralis comb. nov. J. Clin. Microbiol. 23:1114-20

16. Buchanan, R. E., Gibbons. N. E., eds. 1974. Bergey's Manual of Determinative Bacteriology. Baltimore: Williams \& Wilkins. 1246 pp. 8th ed.

17. Buchanan, R. E., Holt, J. G., Lessel, E. F., eds. 1966. Index Bergeyana-An Annotated Alphabetic Listing of Names of the Taxa of the Bacteria. Baltimore: Williams \& Wilkins. 1472 pp.

18. Buddenhagen, I., Kelman, A. 1964. Biological and physiological aspects of bacterial wilt caused by Pseudomonas solanacearum. Annu. Rev. Phytopathol. 2:203-30

19. Burkholder, W. H., Starr, M. P. The generic and specific characters of phytopathogenic species of Pseudomonas and Xanthomonas. Phytopathology 38:494-502

20. Byng, G. S., Whitaker, R. J., Gherna, R. L., Jensen, R. A. 1980. Variable enzymological patterning in tyrosinase biosynthesis as a means of determining natural relatedness among the Pseudomonadaceae. J. Bacteriol. 144:247-57

21. Carlson, R. R., Vidaver, A. K. 1982. Taxonomy of Corynebacterium plant pathogens, including a new pathogen of wheat, based on polyacrylamide gel electrophoresis of cellular proteins. Int. J. Syst. Bacteriol. 32:315-26
22. Champion, A. B., Barrett, E. L., Palleroni, N. J., Soderberg, K. L., Kunisawa, R. et al. 1980. Evolution in Pseudomonas fluorescens. J. Gen. Microbiol. 120:485-511

23. Civerolo, E. L., Collmer, A., Davis, R. E., Gillaspie, A. G., eds. 1987. Plant Pathogenic Bacteria. Proc. Int. Conf. Plant Pathog. Bact., 6th, Beltsville, 1985. Dordrecht: Martinus Nijhoff. $1050 \mathrm{pp}$.

24. Collins, M. D., Bradbury, J. 1986. Plant pathogenic species of Corynebacterium. See Ref. 150, pp. 127683

25. Collins, M. D., Jones, D. 1981. Distribution of isoprenoid quinone structural types in bacteria and their taxonomic implications. Microbiol. Rev. 45:31654

26. Collins, M. D., Jones, D. 1983. Reclassification of Corynebacterium flaccumfaciens, Corynebacterium betae, Corynebacterium oortii and Corynebacterium poinsettiae in the genus Curtobacterium, as Curtobacterium flaccumfaciens comb. nov. J. Gen. Microbiol. 129:3545-48

27. Collins, M. D., Jones, D., Kroppenstedt, R. M. 1981. Reclassification of Corynebacterium ilicis (Mandel, Guba and Litsky) in the genus Arthrobacter, as Arthrobacter ilicis comb. nov. Zentralbl. Bakteriol. Mikrobiol. Hyg. Abt. I. Orig. C2:318-23

28. Colwell, R. R. 1970. Polyphasic taxonomy of bacteria. In Culture Collections of Microorganisms, ed. H. Iizuka, T. Hasegawa, 421-36. Baltimore: Univ. Park Press. 625 pp.

29. Cook, D., Barlow, E., Sequeira, L. 1989. Genetic diversity of Pseudomonas solanacearum: detection of restriction fragment length polymorphisms with DNA probes that specify virulence and the hypersensitive response. Mol. PlantMicrob. Interact. 2:113-21

30. Crombach, W. H. J. 1978. DNA base ratios and DNA hybridisation studies of coryneform bacteria, mycobacteria and nocardiae. See Ref. 8, pp. 16179

31. Davis, M. J., Gillaspie, A. G., Vidaver, A. K., Harris, R. W. 1984. Clavibacter: a new genus containing some phytopathogenic coryneform bacteria, including Clavibacter xyli subsp. xyli sp. nov., subsp. nov. and Clavibacter xyli subsp. cynodontis subsp. nov., pathogens that cause ratoon stunting disease of sugarcane and Bermudagrass stunting disease. Int. J. Syst. Bacteriol. 34:107-17 
32. Davis, P. H., Hayward, V. H. 1963. Principles of Angiosperm Taxonomy. Edinburgh: Oliver \& Boyd. $556 \mathrm{pp}$.

33. De Ley, J. 1978. Modern molecular methods in bacterial taxonomy: evaluation, application, prospects. See Ref. 164 , Vol. 1, pp. 347-57

34. Demaree, J. B., Smith, N. R. 1952. Nocardia vaccinii $\mathrm{n}$. $\mathrm{sp}$. causing galls of blueberry plants. Phytopathology 42: 249-52

35. Denny, T. P. 1988. Phenotypic diversity in Pseudomonas syringae pv. tomato. J. Gen. Microbiol. 134:1939-48

36. Denny, T. P., Gilmour, M. N., Selander, R. K. 1988. Genetic diversity and relationships of two pathovars of Pseudomonas syringae. J. Gen. Microbiol. 134:1949-60

37. De Parasis, J., Roth, D. A. 1990. Nucleic acid probes for identification of phytobacteria: identification of genusspecific 16s rRNA sequences. Phytopathology 80:618-21

38. De Vos, P., De Ley, J. 1983. Intra- and intergeneric similarities of Pseudomonas and Xanthomonas ribosomal ribonucleic acid cistrons. Int. J. Syst. Bacteriol. 33:487-509

39. De Vos, P., Goor, M., Gillis, M., De Ley, J. 1985. Ribosomal ribonucleic acid cistron similarities of phytopathogenic Pseudomonas species. Int. J. Syst . Bacteriol. 35:169-84

40. Dickey, R. S. 1981. Erwinia chrysanthemi: reactions of eight plant species to strains from several hosts and to strains of other Erwinia species. Phytopathology $71: 23-29$

41. Doolittle, W. F. 1988. Bacterial evolution. Can J. Microbiol. 34:547-51

42. Dopfer, H., Stackebrandt, E., Fiedler, F. 1982. Nucleic acid hybridization studies on Microbacterium, Curtobacterium, Agromyces and related taxa. $J$. Gen. Microbiol. 128:1697-708

43. Doudoroff, M., Palleroni, N. J. 1974. Pseudomonas Migula 1894. See Ref. 16, pp. 217-43

44. Dye, D. W. 1962. The inadequacy of the usual determinative tests for the identification of Xanthomonas spp. $N$. Z. J. Sci. 5:393-416

45. Dye, D. W. 1981. A numerical taxonomic study of the genus Erwinia. N. Z. J. Agric. Res. 24:223-29

46. Dye, D. W., Bradbury, J. F., Dickey, R. S., Goto, M., Hale, C. N., et al. 1974. The problem of nomenclature of plant pathogenic pseudomonads. Rev. Plant Pathol. 53:953-62

47. Dye, D. W., Bradbury, J. F., Goto, M.,
Hayward, A. C., Lelliott, R. A., et al. 1980. International standards for naming pathovars of phytopathogenic bacteria and a list of pathovar names and pathotype strains. Rev. Plant. Pathol. 59: 153-68

48. Dye, D. W., Kemp, W. J. 1977. A taxonomic study of the plant pathogenic Corynebacterium species. N. Z. J. Agric. Res. 20:563-82

49. Dye, D. W., Lelliott, R. A. 1974. Xanthomonas Dowson 1939. See Ref. 16, pp. 243-49

50. Egel, D. S., Graham, J. H., Stall, R. E. 1991. Genomic relatedness of Xanthomonas campestris strains causing diseases of citrus. Appl. Env. Microbiol. 57:2724-30

51. Elliott, C. 1951. Manual of Bacterial Plant Pathogens. Waltham, MA: Chronica Botanica. 186 pp. 2nd ed.

51a. Ercolani, G. L. 1984. Infectivity titration with bacterial plant pathogens. Annu. Rev. Phytopathol. 22:35-52

52. Ercolani, G. L. 1987. Practical problems with the pathovar scheme in plant quarantine. See Ref. 23, pp. 786-94

53. Felsenstein, J. 1988. Phylogenies from molecular sequences: inference and reliability. Annu. Rev. Genet. 22:52165

54. Firrao, G., Locci, R. 1989. Identification by probabilistic methods of plant pathogenic bacteria. Ann. Microbiol. Enzimol. 39:81-92

55. Gabriel, D. W., Hunter, J. E., Kingsley, M. T., Miller, J. W. Lazo, G. R. 1988. Clonal population structure of Xanthomonas campestris and genetic diversity among citrus canker strains. Mol. Plant-Microb. Interact. 1:59-65

55a. Gardan, L., Cottin, S., Bollet, C., Hunault, G. 1991 Phenotypic heterogeneity of Pseudomonas syringae van Hall 1902. Res. Microbiol. 142:995-1003

56. Gavini, F., Mergaert, J., Beji, A., Mielcarek, C., Izard, D., et al. 1989. Transfer of Enterobacter agglomerans (Beijerinck 1888) Ewing \& Fife 1972 to Pantoea gen. nov. as Pantoea agglomerans comb. nov. and description of Pantoea dispersa. Int. J. Syst. Bacteriol. 39:337-45

57. Goodfellow, M. 1984. Reclassification of Corynebacterium fascians (Tilford) Dowson in the genus Rhodococcus, as Rhodococcus fascians comb. nov. Syst. Appl. Microbiol. 5:225-29

58. Goodfellow, M. 1986. Genus Rhodococcus Zopf 1891. See ref. 150, pp. 1472-81

59. Goodfellow, M., Jones, D., Priest, F. 
G., eds. 1985. Computer-assisted Bacterial Systematics. London: Academic. $443 \mathrm{pp}$.

59a. Goodfellow, M., Lechevalier, M. P. 1986. Genus Nocardia Trevisan 1889. See Ref. 150, pp. 1459-71

60. Goodfellow, M., Minnikin, D. E. 1981. The genera Nocardia and Rhodococcus. See Ref. 163, Vol. 2, pp. 2016-27

61. Goodfellow, M., Minnikin, D. E., eds. 1985. Chemical Methods in Bacterial Systematics. London: Academic. 410 pp.

62. Gordon, R. E. 1978. A species definition. Int. J. Syst. Bacteriol. 28:605-7

63. Graham, J. H., Hartung, J. S., Stall, R. E., Chase, A. R. 1990. Pathological, restriction-fragment length polymorphism, and fatty acid profile relationships between Xanthomonas campestris from citrus and noncitrus hosts. Phytopathology 80:829-36

64. Hampton, R., Ball, E., De Boer, S., eds. 1990. Serological Methods for Detection and Identification of Viral and Bacterial Plant Pathogens-A Laboratory Manual. St Paul: Am. Phytopathol. Soc. 389 pp.

65. Hartford, T., Sneath, P. H. A. 1990. Experimental error in DNA-DNA pairing: a survey of the literature. $J$. Appl. Bacteriol. 68:527-42

66. Hartung, J. S., Civerolo, E. L. 1989. Restriction fragment length polymorphisms distinguish Xanthomonas campestris strains isolated from Florida citrus nurseries from $X$. c. pv. citri. Phytopathology 79:793-99

67. Hawksworth, D. L., ed. 1988. Prospects in Systematics. Oxford: Clarendon. 457 pp.

68. Hayward, A. C. 1964. Characteristics of Pseudomonas solanacearum. J. Appl. Bacteriol. 27:265-77

69. Hayward, A. C. 1972. The impact of changes in nomenclature on plant quarantine measures. See Ref. 107, pp. 29394

70. Hayward, A. C. 1983. Pseudomonas: the non-fluorescent pseudomonads. In Plant Bacterial Diseases-A Diagnostic Guide, ed. P. C. Fahy, G. J. Persley, pp. 107-40. Sydney: Academic. 393 pp.

71. Henningson, P. J., Gudmestad, N. C 1991. Fatty acid analysis of phytopathogenic coryneform bacteria. J. Gen. Microbiol. 137:427-40

72. Heslop-Harrison, J. 1962. Purposes and procedures in the taxonomic treatment of higher organisms. In Microbial Classification. Symp. Soc. Gen. Microbiol., 12th, London, pp. 14-36. Cambridge: Cambridge Univ. Press. 483 pp.
73. Hildebrand, D. C., Palleroni, N. J., Schroth, M. N. 1990. Deoxyribonucleic acid relatedness of 24 xanthomonad strains representing 23 Xanthomonas campestris pathovars and Xanthomonas fragariae. J. Appl. Bacteriol. 68:263-69

74. Hildebrand, D. C., Schroth, M. N., Huisman, O. C. 1982. The DNA homology matrix and non-random variation concepts as the basis for the taxonomic treatment of plant pathogenic and other bacteria. Annu. Rev. Phytopathol. 20:235-56

75. Hildebrand, D. C., Schroth, M. N., Sands, D. C. 1988. Pseudomonas. See Ref. 137 , pp. $60-80$

76. Hirano, S. S., Upper, C. D. 1990. Population biology and epidemiology of Pseudomonas syringae. Annu. Rev. Phytopathol. 28:155-77

77. Holmes, B. 1988. Taxonomy of Agrobacterium. Acta Hortic. 225:47-52

78. Holmes, B., Roberts, P. 1981. The classification, identification and nomenclature of agrobacteria. J. Appl. Bacteriol. 50:443-67

79. Hopkins, D. L. 1989. Xylella fastidiosa: xylem-limited bacterial pathogen of plants. Annu. Rev. Phytopathol. 27: 271-90

80. Hu, F-P., Young, J. M., Triggs, C. M. 1991. Numerical analysis and determinative tests for nonfluorescent plant-pathogenic Pseudomonas spp. and genomic analysis and reclassification of species related to Pseudomonas avenae Manns 1909. Int. J. Syst. Bacteriol. 41:516-525

81. Jones, D. 1978. An evaluation of the contributions of numerical taxonomic studies to the classification of coryneform bacteria. See Ref. 8, pp. 13-46

82. Jones, D. 1983. Impact of plasmids and transposons on microbial systems. In Microbiology-1983, ed. D. Schlessinger, 119-24. Washington, DC: Am. Soc. Microbiol. 412 pp.

83. Jones, D., Collins, M. D. 1986. Irregular, non-sporing gram-positive rods. See Ref. 150, pp. 1261-66

84. Jones, D., Krieg, N. R. 1984. Serology and chemotaxonomy. See Ref. 98, pp. 15-18

85. Jones, D., Sneath, P. H. A. 1970. Genetic transfer and bacterial taxonomy. Bacteriol. Rev. 34:40-81

86. Joysey, K. A. 1988. Some implications of the revolution in molecular biology. See Ref. 67, pp. 202-16

87. Judicial Commission. 1970. Opinion 33. Conservation of the generic name Agrobacterium Conn 1942. Int. J. Syst. Bacteriol. 20:10 
88. Keane, P. J., Kerr, A., New, P. B. 1970. Crown gall of stone fruit. II. Identification and nomenclature of Agrobacterium isolates. Aust. J. Biol. Sci. 23:585-95

89. Kerr, A. 1991. The genus Agrobacterium. See Ref. 3a, 3:2214-35

90. Kerr, A., Young, J. M. Panagopoulos, C. G. 1978. Agrobacterium Conn 1942. See Ref. 199, pp. 155-56

91. Kersters, K. 1985. Numerical methods in the classification of bacteria by protein electrophoresis. See Ref. 59, pp. 337-68

92. Kersters, K., De Ley, J. 1984. Genus III. Agrobacterium Conn 1942. See Ref. 98 , pp. 244-54

93. Kersters, K., De Ley, J., Sneath, P. H. A., Sackin, M. 1973. Numerical taxonomic analysis of Agrobacterium. J. Gen. Microbiol. 78:227-39

94. Kersters, K., Pot, B., Hoste, B., Gillis, M., De Ley, J. 1989. Protein electrophoresis and DNA:DNA hybridizations of xanthomonads from grasses and cereals. Bull. OEPP/EPPO Bull. 19:5155

95. Klement, Z. ed. 1990. Plant pathogenic bacteria. Proc. Int. Conf. Plant Pathog. Bact. 7th, Budapest, 1989, Parts A, B. Budapest: Akad. Kiado. 661 pp., 401 pp.

95a. Klement, Z., Rudolph, K., Sands, D. C. 1990. Methods in Phytobacteriology. Budapest: Akad. Kiado. 568 pp.

96. Krawiec, S. 1985. Concept of a bacterial species. Int. J. Syst. Bacteriol. 35:21720

97. Krieg, N. R. 1988. Bacterial classification: an overview. Can. J. Microbiol. 34:536-40

98. Krieg, N. R., Holt, J. G., eds. 1984. Bergey's Manual of Systematic Bacteriology, Vol. 1. Baltimore: Williams \& Wilkins. $964 \mathrm{pp}$.

99. Lapage, S. P., Sneath, P. H. A., Lessel, E. F., Skerman, V. B. D., Seeliger, H. P. R., et al, eds. 1975. International Code of Nomenclature of Bacteria. Washington, DC: Am. Soc. Microbiol. $180 \mathrm{pp}$.

100. Lazo, G. R., Roffey, R., Gabriel, D. W. 1987. Pathovars of Xanthomonas campestris are distinguishable by restriction fragment-length polymorphism. Int J. Syst. Bacteriol. 37:214-21

101. Deleted in proof

102. Lelliott, R. A. 1972. The genus Xanthomonas. See Ref. 107, pp. 269-72

103. Lelliott, R. A., Billing, E., Hayward, A. C. 1966. A determinative scheme for the fluorescent plant pathogenic pseudomonads. J. Appl. Bacteriol. 29:470-89
104. Lelliott, R. A., Dickey, R. S. 1984. Genus Erwinia Winslow, Broadhurst, Buchanan, Krumwiede, Rogers and Smith 1920. See Ref. 98, pp. 46976

105. Leyns, F., De Cleene, M., Swings, J-G., De Ley, J. 1984. The host range of the genus Xanthomonas. Bot. Rev. 50:308-56

106. Locci, R., Firrao, G., Petrolini, B., Sardi, P. 1989. Numerical taxonomy of phytopathogenic corynebacteria. Ann. Microbiol. Enzimol. 39:59-79

107. Maas Geesteranus H. P., ed. 1972. Plant pathogenic bacteria 1971. Proc. Int. Conf. Plant Pathog. Bact., 3rd. Wageningen, 1971. Wageningen: Pudoc. 365 pp.

108. Martin, R. D. 1990. Primate Origins and Evolution-A Phylogenetic Reconstruction. London: Chapman \& Hall. $804 \mathrm{pp}$.

109. Maynard Smith, J. 1990. The evolution of prokaryotes: does sex matter? Annи. Rev. Ecol. Syst. 21:1-12

110. McNeill, J. 1982. Phylogenetic reconstruction and phenetic taxonomy. Zool. J. Linn. Soc. 74:337-44

111. Mergaert, J., Verdonck, L., Kersters, K., Swings, J., Boeufgras, J-M., et al. 1984. Numerical taxonomy of Erwinia species using API systems. J. Gen. Microbiol. 130:1893-910

112. Miller, S. A., Martin, R. R. 1988. Molecular diagnosis of plant disease. Annu. Rev. Phytopathol. 26:409-32

112a. Mitchell, R. E. 1991. Implications of toxins in the ecology and evolution of plant pathogenic microorganisms: bacteria. Experimentia 47:791-803

113. Murata, N., Starr, M. P. 1973. A concept of the genus Xanthomonas and its species in the light of segmental homology of deoxyribonucleic acids. Phytopathol. Z. 77:285-323

114. Murata, N., Starr, M. P. 1974. Intrageneric clustering and divergence of Erwinia strains from plants and man in the light of deoxyribonucleic acid segmental homology. Can. J. Microbiol. 20:1545-65

115. Murray, R. G. E., Brenner, D. J., Colwell, R. R., De Vos, P., Goodfellow, M., et al. 1990. Report of the ad hoc committee on approaches to taxonomy within the Proteobacteria. Int. J. Syst. Bacteriol. 40:213-15

116. Nester, E. W., Gordon, M. P., Amasino, R. M., Yanofsky, M. F. 1984. Crown gall: a molecular and physiological analysis. Annu. Rev. Plant Physiol. 35:387-413

117. Olsen, G. J. 1988. Phylogenetic analysis 
using ribosomal RNA. Methods Enzymol. 164:793-812

118. Ophel, K., Kerr, A. 1990. Agrobacterium vitis sp. nov. for strains of Agrobacterium biovar 3 from grapevines. Int. $J$. Syst. Bacteriol. 40:236-41

119. Oyaizu, H., Komagata, K. 1983. Grouping of Pseudomonas species on the basis of cellular fatty acid composition and the quinone system with special reference to the existence of 3-hydroxy fatty acids. J. Gen. Appl. Microbiol. 29:17-40

120. Palleroni, N. J. 1984. Genus I Pseudomonas Migula 1894. See Ref. 98, pp. 141-99

121. Panagopoulos, C. G. 1969. The disease "tsilik marasi" of grapevine: its description and identification of the causal agent (Xanthomonas ampelina sp. nov.). Ann. Inst. Phytopatholol. Benaki N.S. 9:59-81

122. Patterson, C. 1988. The impact of evolutionary theories on systematics. See Ref. 67, pp. 59-91

123. Pecknold, P. C., Grogan R. G. 1973. Deoxyribonucleic acid homology groups among phytopathogenic Pseudomonas species. Int. J. Syst. Bacteriol. 23:11121

124. Pérombelon, M. C. M. 1991. The genus Erwinia. See Ref. 3a, 3: 2899-921

125. Qhobela, M., Claflin, L. E., Nowell, D. C. 1990. Evidence that Xanthomonas campestris pv. zeae can be distinguished from the other pathovars capable of infecting maize by restriction fragment length polymorphism of genomic DNA. Can. J. Plant Pathol. 12:183-86

126. Ramundo, B. A., Claflin, L. E. 1990. Demonstration of synonymy between the plant pathogens Pseudomonas avenae and Pseudomonas rubrilineans. $J$. Gen. Microbiol. 136:2029-33

127. Ravin, A. W. 1963. Experimental approaches to the study of bacterial phylogeny. Am. Nat. 97:307-18

128. Riley, I. T. 1987. Serological relationships between strains of coryneform bacteria responsible for annual ryegrass toxicity and other plant-pathogenic bacteria. Int. J. Syst. Bacteriol. 37:15359

129. Riley, I. T., Reardon, T. B., McKay, A. C. 1988. Genetic analysis of plant pathogenic bacteria in the genus Clavibacter using allozyme electrophoresis. J. Gen. Microbiol. 134:3025-30

130. Roberts, S. J., Eden-Green, S. J., Jones, P., Ambler, D. J. 1990. Pseudomonas syzygii, sp. nov., the cause of Sumatra disease of cloves. Syst. Appl. Microbiol. 13:34-43
131. Sackin, M. J. 1985. Comparisons of classifications. See Ref. 59, pp. 21-36

132. Samson, R., Nassan-Agha, N. 1978. Biovars and serovars among 129 strains of Erwinia chrysanthemi. See Ref. 164, Vol. 2, pp. 547-53

133. Sands, D. C., Schroth, M. N., Hildebrand, D. C. 1970. Taxonomy of phytopathogenic pseudomonads. J. Bacteriol. 101:9-23

134. Schaad, N. W. 1979. Serological identification of plant pathogenic bacteria. Annu. Rev. Phytopathol. 17:123-47

135. Schaad, N. W. 1982. How phytopathogenic prokaryotes are classified. In Phytopathogenic Prokaryotes, ed. M. S. Mount, G. H. Lacey, 1:19-29. New York: Academic. 541 pp.

136. Schaad, N. W. 1987. Problems with the pathovar concept. See Ref. 23, pp. 78385

137. Schaad, N. W., ed. 1988. Laboratory Guide for Identification of Plant Pathogenic Bacteria. St Paul: APS Press. 158 pp. 2nd ed.

138. Schleifer, K. H., Stackebrandt, E. 1983. Molecular systematics of prokaryotes. Annu. Rev. Microbiol. 37:143-87

139. Schroth, M. N., Hildebrand, D. C. 1983. Toward a sensible taxonomy of bacterial plant pathogens. Plant Dis. $67: 128$

140. Schroth, M. N., Hildebrand, D. C., Starr, M. P. 1981. Phytopathogenic members of the genus Pseudomonas. See Ref. 163, pp. 701-18

141. Scott-Ram, N. R. Transformed Cladistics. Cambridge: Cambridge Univ. Press. 238 pp.

142. Seiler, H. 1983. Identification key for coryneform bacteria derived by numerical taxonomic studies. J. Gen. Microbiol. 129:1433-71

143. Simpson, G. G. 1945. The principles of classification and a classification of mammals. Bull. Am. Mus. Nat. Hist. 85:1-350

144. Skerman, V. B. D., McGowan, V., Sneath, P. H. A., eds. 1980. Approved lists of bacterial names. Int. J. Syst. Bacteriol. 30:225-420

145. Sneath, P. H. A. 1984. Numerical taxonomy. See Ref. 98, pp. 5-7

146. Sneath, P. H. A. 1984. Bacterial nomenclature. See Ref. 98, pp. 19-23

147. Sneath, P. H. A. 1985. Future of numerical taxonomy. See Ref. 59, pp. 41531

148. Sneath, P. H. A. 1988. The phenetic and cladistic approaches. See Ref. 67, pp. 252-73

149. Sneath, P. H. A. 1989. Analysis and interpretation of sequence data for bacte- 
rial systematics: the view of a numerical taxonomist. Syst. Appl. Microbiol. 12: $15-31$

150. Sneath, P. H. A., Mair, N. S., Sharpe, M. E., eds. 1986. Bergey's Manual of Systematic Bacteriology, Vol. 2. Baltimore: Williams \& Wilkins. 635 pp.

151. Sneath, P. H. A., Stevens, M., Sackin, M. J. 1981. Numerical taxonomy of Pseudomonas based on published records of substrate utilization. Antonie van Leeuwenhoek J. Microbiol. Serol. 47: 423-48

152. Sokal, R. R., Sneath, P. H. A. 1963. Principles of Numerical Taxonomy. San Francisco: Freeman. 359 pp.

153. Stackebrandt, E. 1988. Phylogenetic relationships vs. phenotypic diversity: how to achieve a phylogenetic classification system of the eubacteria. Can. J. Microbiol. 34:552-66

154. Stackebrandt, E., Goodfellow, M., eds. 1991. Nucleic Acid Techniques in Bacterial Systematics. Chichester: Wiley. 329 pp.

155. Stackebrandt, E., Murray, R. G. E., Trüper, H. G. 1988. Proteobacteria classis nov., a name for the phylogenetic taxon that includes the "purple bacteria and their relatives." Int. J. Syst. Bacteriol. 38:321-25

156. Stackebrandt, E., Woese, C. R. 1984. The phylogeny of the prokaryotes. Microbiol. Sci. 1:117-22

157. Staley, J. T., Krieg, N. R. 1984. Classification of prokaryotic organisms: an overview. See Ref. 98, pp. 1-4

158. Stall, R. E., Minsavage, G. V. 1990. The use of hrp genes to identify opportunistic xanthomonads. See Ref. 95, pp. $369-74$

159. Stanier, R. Y., Palleroni, N. J., Doudoroff, M. 1966. The aerobic pseudomonads: a taxonomic study. J. Gen. Microbiol. 43:159-271

160. Starr, M. P. 1959. Bacteria as plant pathogens. Апnи. Rev. Microbiol. 13: 211-38

161. Starr, M. P. 1981. The genus Xanthomonas. See Ref. 163, Vol. 1, pp. 74263

162. Starr, M. P., Mandel, M. 1969. DNA base composition and taxonomy of phytopathogenic and other enterobacteria. $J$. Gen. Microbiol. 56:113-23

163. Starr, M. P., Stolp, H., Trüper, H. G., Balows, A., Schlegel, H. G., eds. 1981. The Prokaryotes: A Handbook on Habitats, Isolation and Identification of Bacteria, Vols. 1, 2. Berlin: SpringerVerlag. 1102 pp., 1182 pp.

164. Station de Pathologie Végétale et Phytobactériologie. 1978. Plant Pathogenic
Bacteria. Proc. Int. Conf. Plant Pathog. Bact., 5th, Angers. Vols. 1, 2. Angers: Inst. Natl. Rech. Agron. 399 pp., 580 pp.

165. Stead, D. E. 1989. Grouping of Xanthomonas campestris pathovars of cereals and grasses by fatty acid profiling. Bull. OEPP/EPPO Bull. 19:57-68

166. Stead, D. E. 1990. Evaluation of cellular fatty acid profiles for rapid identification of plant pathogenic bacteria. See Ref. 95, Part A, pp. 483-90

167. Stead, D. E. 1992. Classification of $P$. syringae pathovars by fatty acid profiling. In Proc. Int. Work. Group Pseudomonas syringae, 4th, Firenze, 1991.pp. 381-90. Int. Soc. Plant Pathol. Univ. Florence. $439 \mathrm{pp}$.

168. Stead, D. E. Grouping of plant pathogenic and some other Pseudomonas spp. using cellular fatty acid profiles. Int. J. Syst. Bacteriol. In press

169. Steigerwalt, A. G., Fanning, G. R., Fife-Asbury, M. A., Brenner, D. J. 1976. DNA relatedness among species of Enterobacter and Serratia. Can. J. Microbiol. 22:121-37

170. Stolp, H., Starr, M. P., Baigent, N. L. 1965. Problems in speciation of phytopathogenic pseudomonads and xanthomonads. Annu. Rev. Phytopathol. 3:231-64

171. Swings, J., Hayward, A. C. 1990. Taxonomy. See Ref. 95a, pp. 125-31

172. Swings, J., Van den Mooter, M., Vauterin, L., Hoste, B., Gillis, M., et al. 1990. Reclassification of the causal agents of bacterial blight (Xanthomonas campestris pv. oryzae) and bacterial leaf streak (Xanthomonas campestris pv. oryzicola) of rice as pathovars of Xanthomonas oryzae (ex Ishiyama 1922) sp. nov., nom. rev. Int. J. Syst. Bacteriol. 40:309-11

173. Takikawa, Y. 1990. Chemotaxonomic and phenotypic characterization of phytopathogenic pseudomonads. See Ref. 95, Part A, pp. 449-55

174. Tesic, Z. 1972. The use of 'special forms' in the classification of phytopathogenic bacteria. See Ref. 107, pp. 295 98

175. Thorpe, J. P. 1982. The molecular clock hypothesis: biochemical evolution, genetic differentiation and systematics. Annu. Rev. Ecol. Syst. 13:139-68

176. Trüper, H. G., Kramer, J. 1981. Principles of characterization and identification of prokaryotes. See Ref. 163, Vol. 1, pp. 176-93

177. Van Bruggen, A. H. C., Jochimsen, K. N., Brown, P. R. 1990. Rhizomonas suberifaciens gen. nov., sp. nov., the 
causal agent of corky root of lettuce. Int J. Syst. Bacteriol. 40:175-88

178. Van den Mooter, M., Steenackers, M., Maertens, C., Gosselé, F., De Vos, P., et al. 1987. Differentiation between $X$. campestris pv. graminis (ISPP List 1980), pv. phleipratensis (ISPP List 1980) emend., pv. poae Egli and Schmidt 1982 and pv. arrhenatheri Egli and Schmidt 1982, by numerical analysis of phenotypic features and protein gel electrophoregrams. J. Phytopathol. 118:135-56

179. Van den Mooter, M., Swings, J. 1990. Numerical analysis of 295 phenotypic features of 266 Xanthomonas strains and related strains and an improved taxonomy of the genus. Int. J. Syst. Bacteriol. 40:348-69

180. Van Zyl, E., Steyn, P. L. 1990. Differentiation of phytopathogenic Pseudomonas and Xanthomonas species and pathovars by numerical taxonomy and protein gel electrophoregrams. Syst. Appl. Microbiol. 13:60-71

180a. Van Zyl, E., Steyn, P. L. 1992. Reinterpretation of the taxonomic position of Xanthomonas maltophilia and taxonomic criteria in this genus. Int. $J$. Syst. Bacteriol. 42:193-98

181. Vauterin, L., Swings, J., Kersters, K., Gillis, M., Mew, T. W., et al. 1990. Towards an improved taxonomy of Xanthomonas. Int. J. Syst. Bacteriol. 40:312-16

182. Vauterin, L., Swings, J., Kersters, K. 1991. Grouping of Xanthomonas campestris pathovars by SDS-PAGE of proteins. J. Gen. Microbiol. 137:1677-87

183. Vauterin, L., Yang, P., Hoste, B., Vancanneyt, M., Civerolo, E. L., et al 1991. Differentiation of Xanthomonas campestris pv. citri strains by sodium dodecyl sulphate-polyacrylamide gel electrophoresis of proteins, fatty acid analysis, and DNA-DNA hybridization. Int. J. Syst. Bacteriol. 41:535-42

184. Vera Cruz, C. M., Gosselé, F., Kersters, K., Segers, P., Van den Mooter, M., et al. 1984. Differentiation between $X$. campestris pv. oryzae, $X$. campestris pv. oryzicola and the bacterial 'brown blotch' pathogen on rice by numerical analysis of phenotypic features and protein gel electrophoregrams. J. Gen. Microbiol. 130:2983-99

185. Verdonck, L., Mergaert, J., Rijckaert, C., Swings, J., Kersters, K., et al. 1987. Genus Erwinia: numerical analysis of phenotypic features. Int. J. Syst. Bacteriol. 37:4-18

186. Vidaver, A. K., Davis, M. J. 1988. Gram-positive bacteria. A. Coryneform plant pathogens. See Ref. 137, pp. 104 13

187. Waldee, E. L. 1945. Comparative studies of some peritrichous phytopathogenic bacteria. Iowa State Coll. J. Sci. 19:435-84

188. Wayne, L. G., Brenner, D. J., Colwell, R. R., Grimont, P. A. D., Kandler, O., et al. 1987. Report of the ad hoc committee on the reconciliation of approaches to bacterial systematics. Int. J. Syst. Bacteriol. 37:463-64

189. Wells, J. M., Raju, B. C., Hung, H-Y., Weisburg, W. G., Mandelco-Paul, L., Brenner, D. J. 1987. Xylella fastidiosa gen. nov., sp. nov:gram-negative, xylem-limited, fastidious plant bacteria related to Xanthomonas spp. Int. J. Syst. Bacteriol. 37:136-43

190. Willems, A., Busse, J., Goor, M., Pot, B., Falsen, E., et al. 1989. Hydrogenophaga, a new genus of the hydrogen-oxidizing bacteria that includes Hydrogenophaga flava comb. nov. (formerly Pseudomonas flava), Hydrogenophaga palleroni (formerly Pseudomonas palleroni), Hydrogenophaga pseudoflava (formerly Pseudomonas pseudoflava and "Pseudomonas carboxyflava"), and Hydrogenophaga taeniospiralis (formerly Pseudomonas taeniospiralis). Int. J. Syst. Bacteriol. 39:319-33

191. Willems, A., De Ley, J., Gillis, M., Kersters, K. 1991. Comamonadaceae, a new family encompassing the acidovorans rRNA complex, including Variovorax paradoxus gen. nov., comb. nov., for Alcaligenes paradoxus (Davis 1969). Int. J. Syst. Bacteriol. 41:445-50

192. Willems, A., Gillis, M., Kersters, K., Van den Broecke, L., De Ley, J. 1987. Transfer of Xanthomonas ampelina Panagopoulos 1969 to a new genus, Xylophilus gen. nov., as Xylophilus ampelinus (Panagopoulos 1969) comb. nov. Int. J. Syst. Bacteriol. 37:42230

192a. Willems, A., Goor, M., Thielemans, S., Gillis, M., Kersters, K., et al. 1992. Transfer of several phytopathogenic Pseudomonas species to Acidovorax as Acidovorax avenae subsp. avenae subsp. nov., comb. nov., Acidovorax avenae subsp. citrulli, Acidovorax avenae subsp. cattleyae and Acidovorax konjaci. Int. J. Syst. Bacteriol. 42:107-19

193. Woese, C. R. 1987. Bacterial evolution. Microbiol. Rev. 51:221-71

194. Yamada, K., Komagata, K. 1972. Taxonomic studies on coryneform bacteria. V. Classification of coryneform bacteria. J. Gen. Appl. Microbiol. 18: 417-31 
195. Young, J. M. 1991. Pathogenicity and identification of the lilac pathogen, Pseudomonas syringae pv. syringae van Hall 1902. Ann. Appl. Biol. 118:28398

196. Young, J. M., Bradbury, J. F., Davis, R. E., Dickey, R. S., Ercolani, G. L., et al. 1991. Nomenclatural revisions of plant pathogenic bacteria and list of names 1980-1988. Rev. Plant Pathol. 70:211-21

197. Young, J. M., Bradbury, J. F., Gardan, L., Gvozdyak, R. I., Stead, D. E., et al. 1991. Comment on the reinstatement of Xanthomonas citri (ex Hasse 1915) Gabriel et al. 1989 and X. phaseoli (ex Smith 1897) Gabriel et al. 1989: indication of the need for minimal standards in the genus Xanthomonas. Int. J. Syst. Bacteriol. 41:172-77

198. Young, J. M., Bradbury, J. F., Vidaver, A. K. 1990. The impact of molecular biological studies on the nomenclature of plant pathogenic bacteria. See Ref. 95, Part A, pp. 659-61

199. Young, J. M., Dye, D. W., Bradbury, J. F., Panagopoulos, C. G., Robbs, C. F. 1978. A proposed nomenclature and classification for plant pathogenic bacteria. N. Z. J. Agric. Res. 21:153-77

200. Young, J. M., Dye, D. W., Bradbury, J. F., Panagopoulos, C. G., Robbs, C. F. 1978. The use of the term "pathovar" in the classification of plant pathogenic bacteria. See Ref. 164, Vol. 1, pp. 359 63 
